\title{
Advancements of
}

operational oceanography

in the Baltic Sea

Petra Roiha

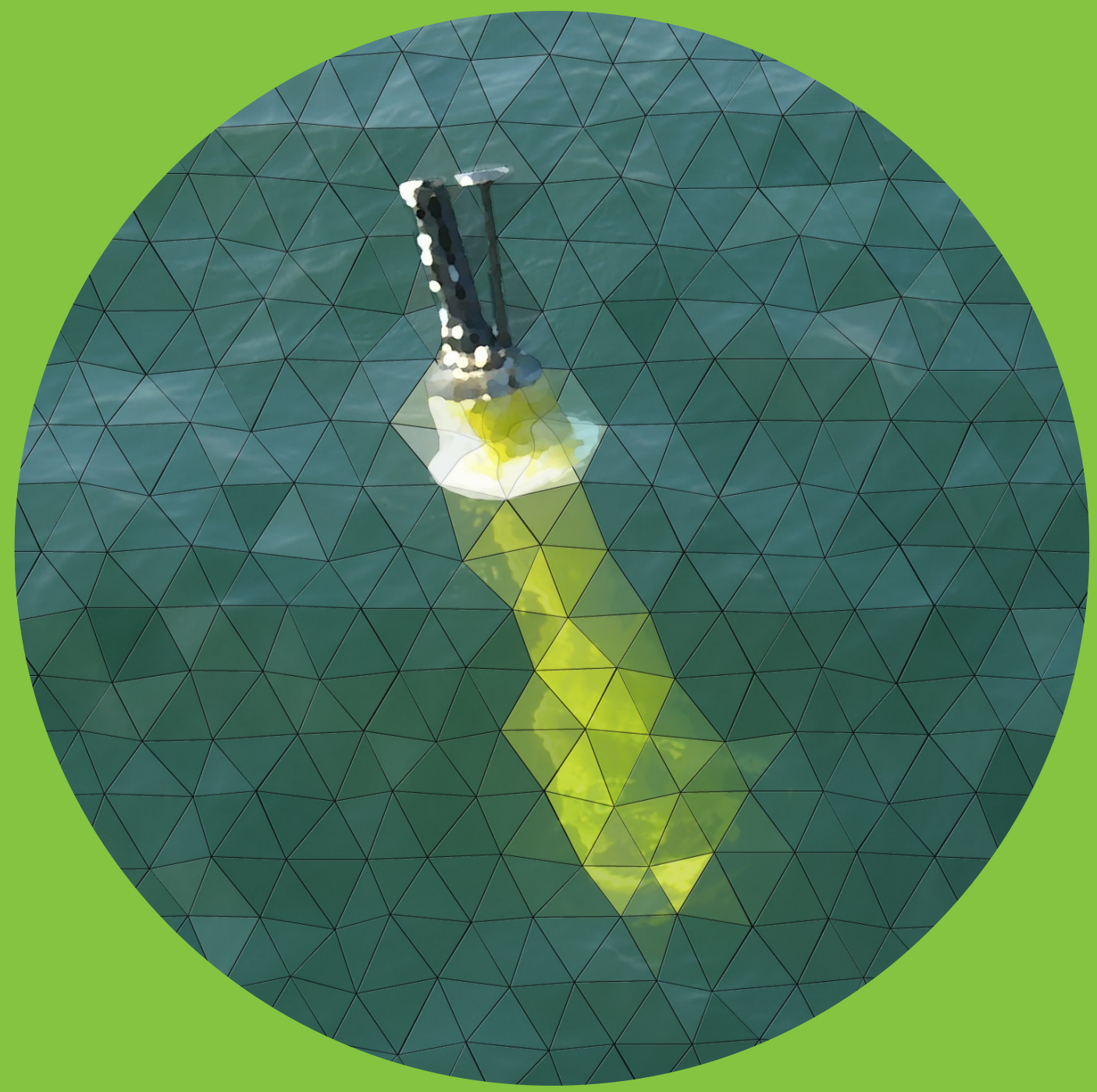




\title{
Advancements of operational oceanography in the Baltic Sea
}

\author{
Petra Roiha
}

A doctoral dissertation completed for the degree of Doctor of Science (Technology) to be defended, with the permission of the Aalto University School of Engineering, at a public examination held at the lecture hall A2 of the school on 20 December 2019 at 12. 


\section{Supervising professor}

Prof. Harri Koivusalo, Aalto University, Finland

\section{Thesis advisor}

Dr Laura Tuomi, Finnish Meteorological Institute, Finland

\section{Preliminary examiners}

Prof. Dr Markus Meier, Leibniz-Institute for Baltic Sea Research (IOW), Germany

Prof. Petteri Uotila, University of Helsinki, Finland

\section{Opponent}

Prof. Dr Markus Meier, Leibniz-Institute for Baltic Sea Research (IOW), Germany

Aalto University publication series

DOCTORAL DISSERTATIONS 221/2019

(C) 2019 Petra Roiha

ISBN 978-952-60-8848-8 (printed)

ISBN 978-952-60-8849-5 (pdf)

ISSN 1799-4934 (printed)

ISSN 1799-4942 (pdf)

http://urn.fi/URN:ISBN:978-952-60-8849-5
ISBN (paperback): 978-952-336-088-4

ISBN (pdf): 978-952-336-089-1

ISSN: 0782-6117

https://doi.org./10.35614/isbn.9789523360891

Images: [Cover] Observing the Sea of Numerics (2019)

Unigrafia Oy

Helsinki 2019

Finland 
Author

Petra Roiha

Name of the doctoral dissertation

Advancements of operational oceanography in the Baltic Sea

Publisher School of Engineering

Unit Department of Built Environment

Series Aalto University publication series DOCTORAL DISSERTATIONS 221/2019

Field of research Water and environmental engineering

Manuscript submitted 13 May 2019

Date of the defence 20 December 2019

Permission for public defence granted (date) 28 October $2019 \quad$ Language English

Monograph

Article dissertation

Essay dissertation

Abstract

Managing the sea environment is a complicated interdisciplinary task. To understand changes in the sea, knowledge of the present state is essential. Many variables are monitored constantly, and long historical data sets exist. However, the spatial and temporal data coverage varies widely over the Baltic Sea. The preparation for the emerging circumstances demands the ability to forecast the future marine conditions. Thus, improved modelling and forecasting systems are needed.

In this thesis, methods were developed to 1) understand the present state of the sea and 2) predict future conditions. The study areas were the Bothnian Sea and the Eastern Gotland Basin.

Argo floats are a common tool in the oceans, but so far they have not been used in shallow marginal seas, such as the Baltic Sea. The autonomous measurement device brings possibilities to fill the gaps in the existing observation network (e.g. research vessels, moorings) as well as to enable new scientific experiments.

To better understand the present state of the Northern Baltic Sea, methods were developed using the Argo floats. The salinity, temperature and GPS data collected with these floats from the area is analysed in this thesis for the first time and its applicability for studying the different physical phenomena, such as currents at the float diving depth and wind induced mixing, are evaluated.

The usability of Argo data was compared with the ship-borne CTD data. Due to the higher frequency of the Argo data, the seasonal variations can be studied in detail with this method. However, the spatial coverage of the Argo data is not as good as the CTD data collected with a research vessel due to the fact that the floats only operate near the deep areas of the Baltic Sea.

To be able to predict the future conditions of the Baltic Sea, monthly ensemble forecasting system was developed. A $3 \mathrm{D}$ biogeochemical model was forced with monthly ensembles of the atmospheric forcing and the results were applied to forecast upwelling events and harmful algal blooms.

The monthly ensemble forecasts for upwelling events were evaluated. The result was that the upwelling events could be forecasted on a weekly scale. This enables, for example, better planning of the scientific study of upwelling events or the improvement of local-scale weather forecasts. The same probability-based ensemble prediction system was used to produce harmful algal bloom forecasts. The forecasts showed the effects of the weather scenarios on marine biogeochemistry.

In the future, it will be possible to interconnect the observations and forecasts better than before. The more dense observations can be used to improve the computational methods, for example, by assimilation. The probability-based forecasts can help, for example, to mitigate the environmental risks.

Keywords operational oceanography, Baltic Sea, Argo, ensemble forecasting, observation, hydrography, harmful algal bloom, upwelling

\begin{tabular}{|c|c|c|}
\hline ISBN (printed) 978-952-60-8848-8 & ISBN (pdf) $978-952-6$ & $0-8849-5$ \\
\hline ISSN (printed) $1799-4934$ & ISSN (pdf) $1799-4942$ & \\
\hline Location of publisher Helsinki & Location of printing Helsinki & Year 2019 \\
\hline Pages 165 & urn http://urn.fi/URN:ISBN:978 & $-952-60-8849-5$ \\
\hline
\end{tabular}



Tekijä

Petra Roiha

Väitöskirjan nimi

Operatiivisen oseanografian edistysaskeleita Itämerellä

\begin{tabular}{lr}
\hline Julkaisija Insinööritieteiden korkeakoulu \\
\hline Yksikkö Rakennetun ympäristön laitos \\
\hline Sarja Aalto University publication series DOCTORAL DISSERTATIONS 221/2019 \\
\hline \multicolumn{2}{l}{ Tutkimusala Vesi- ja ympäristötekniikka } \\
\hline Käsikirjoituksen pvm 13.05 .2019 & Väitöspäivä 20.12.2019 \\
\hline Väittelyluvan myöntämispäivä 28.10 .2019 & Kieli Englanti \\
\hline$\square$ Monografia $\quad \square$ Artikkeliväitöskirja & $\square$ Esseeväitöskirja \\
\hline
\end{tabular}

Tiivistelmä

Meren ilmiöiden tuntemus ja sitä kautta niiden tutkimus, hoito ja kestävä käyttö perustuvat saatavilla olevaan tietoon meren tilasta. Monia meren ympäristömuuttujia mitataan säännöllisesti ja joistain on olemassa jopa pitkiä historiallisia aikasarjoja, mutta aineiston alueellinen ja ajallinen kattavuus vaihtelee suuresti. Myös monet meressä tapahtuvat fysikaaliset, kemialliset ja biologiset prosessit vaikuttavat toisiinsa ja niiden mittakaavat vaihtelevat. Meren nykytilan tuntemuksen lisäksi on kyettävä ennakoimaan tulevia olosuhteita, jotta niihin voidaan varautua.Tässä työssä kehitettiin menetelmiä, joilla voidaan 1) tutkia Itämeren nykytilaa ja 2) ennustaa sen tulevaa tilaa. Pohjoisen Itämeren nykytilan analyysiä varten havaintoaineistoa on kerätty vapaasti ajelehtivilla Argo-poijuilla. Niiden keräämää suolaisuus-, lämpötila- ja sijaintiaineistoja analysoitiin tässä työssä ensimmäistä kertaa ja niiden soveltuvuutta arvioitiin erilaisten ilmiöiden, kuten ajelehtimissyvyyden virtausten ja tuulen aiheuttaman sekoittumisen tutkimukseen.

Itämeren tulevan tilan ennustamiseen kehitettiin kuukausiparviennustemenetelmä, jossa kolmiulotteista biogeokemiallista merimallia ajettiin ilmakehäennusteparven avulla ja tuotettujen parviennusteiden soveltuvuutta arvioitiin kumpuamisten ja sinileväkukintojen ennustamiseen.

Argo-poijuja voidaan käyttää sellaisilla merialueilla ja olosuhteissa, joissa esimerkiksi laivahavaintojen tai kiinteiden ankkurointien käyttäminen on syystä tai toisesta hankalaa. Poijujen profilointitiheyttä voidaan säädellä aikavälillä muutamista tunneista viikkoihin, riippuen siitä millaisen mittaluokan ilmiöitä halutaan havainnoida. Saatua dataa verrattiin tutkimusaluksilta mitattuihin CTD-havaintoihin ja huomattiin että Argo-poijut mahdollistavat vuodenaikaisvaihteluiden tarkemman analyysin. Toisaalta niiden alueellinen kattavuus oli heikompi kuin esimerkiksi tutkimusalusten. Argo-poijujen avulla on myös mahdollista kerätä dataa poijujen liikkeistä sukellussyvyydellä.

Kuukausiparviennusteiden ennustepituutta ja ennusteiden osuvuutta arvioitiin kumpuamisten ennustamisessa Selkämerellä. Havaittiin, että kumpuamisia voidaan ennustaa tällä menetelmällä noin pari viikkoa etukäteen. Tämä mahdollistaa esimerkiksi kumpuamistutkimusten paremman suunnittelun. Samalla parviennustemenetelmää kehitettiin pidemmälle tuottamalla myös sinileväennusteita ja havaittiin, että nämä soveltuvat ennustamaan sinileväkukintojen todennäköisyyttä.

Tulevaisuudessa näitä havaintoja ja ennusteita voidaan soveltaa entistä paremmin. Havaintoja voidaan käyttää laskennallisten työkalujen parantamiseen, esimerkiksi assimiloimalla mittausaineistoa malleihin. Ennusteita voidaan käyttää havaintoverkoston ja in-situ tutkimusten optimointiin ja ympäristöriskien hallintaan.

Avainsanat operatiivinen oseanografia, Itämeri, Argo, parviennusteet, hydrografia, sinileväkukinta, kumpuaminen

\begin{tabular}{|c|c|c|}
\hline ISBN (painettu) 978-952-60 & ISBN (pd & $0-8849-5$ \\
\hline ISSN (painettu) 1799-4934 & ISSN (pd & \\
\hline Julkaisupaikka Helsinki & Painopaikka Helsinki & Vuosi 2019 \\
\hline
\end{tabular}





\section{Acknowledgements}

I would like to express my great appreciation to my former and present supervisors and advisors: Prof. Tuomo Karvonen, Prof. Pertti Vakkilainen, Prof. Harri Koivusalo, Teemu Kokkonen and Laura Tuomi for their constructive suggestions and advice during this project.

My superiors at the Finnish Meteorological Institute (FMI) have always been supportive on my scientific pursuits. I am grateful to Tapani Stipa, Jari Haapala and Laura Tuomi for many interesting research projects I have been able to take part. I want to also thank Maa- ja Vesitekniikan tuki ry. and Sven Hallin Research Foundation sr. for financial support in the beginning of my $\mathrm{PhD}$ studies.

This work could not have been completed without insightful pre-examiners: Prof. Markus Meier and Prof. Petteri Uotila, whose comments were helpful and their enthusiasm for the topic was inspirational. I also want to thank Prof. Meier for accepting the invitation to act as my opponent at the public examination. I would like to extend my thanks to all peer reviewers for their time and insights for improving the articles included in this thesis.

The articles in this thesis have been done in co-operation and interaction with many skillful coauthors and scientists. Special thanks should be given to Pekka Alenius, Noora Haavisto, Aleksi Nummelin,Tero Purokoski, Simo Siiriä and Antti Westerlund for their valuable contribution. I also want to thank all the field personnel in FMI, Finnish Environment Institute, $R / V$ Aranda and Finnish Border Guard for making the magic happen in-situ.

I want to thank teachers and lecturers for sharing their time and knowledge. I am particularly grateful to Terhi Renko whose undergraduate courses on computational fluid dynamics were exciting and inevitably steered my scientific interests towards numerical modelling. 
The colleagues, friends and fellow $\mathrm{PhD}$ students have made the work more enjoyable during these years. I very much appreciate all of my colleagues in marine research for creating inspiring working atmosphere. Even though I have been working over a decade as a marine scientist in Kumpula, I always felt warmly welcome every time I visited Water and Environmental Engineering unit in Otaniemi. I wish to give special thanks to Ulrike, Lassi, Outi, Tero, Laura, Jaana and Maiju for memorable moments and adventures, whether in work or leisure.

I would like to express my very great appreciation to my family and friends, who have helped me since the beginning. Anna \& the Tupeli family, thank you for the tea and sympathy. I would like to thank my parents as well as my parents-in-law, whose love and care have been with me. Most importantly, I wish to thank my loving and endlessly (peer) supportive spouse, Antti, and my wonderful son, Otso. With you every day has a share of joy, curiosity and love. You are my $A$ ja $O$.

Petra Roiha

Helsinki, November 2019 


\section{Contents}

List of Publications $\quad$ v

Author's Contribution vii

1. Introduction 1

1.1 Background . . . . . . . . . . . . . . 1

1.1.1 The Bothnian Sea and Eastern Gotland Basin . 1

1.1.2 Operational oceanography and marine management . . . . . . . . . . . 11

1.1.3 Argo floats . . . . . . . . . . . . 15

1.1.4 Hydrodynamic modelling and forecasting . . . . 17

1.2 The Research Gap . . . . . . . . . . . . . . . . . . . 19

1.3 Objectives .................... 20

2. Materials and Methods 23

2.1 Argo floats in the Baltic Sea . . . . . . . . . . 23

2.1.1 Measured variables and units . . . . . . . . . 24

2.1.2 The persistency of the currents . . . . . . . 27

2.1.3 The monthly mean values . . . . . . . . 28

2.2 The forecasting system $\ldots \ldots \ldots \ldots$

2.2.1 The BALECO model . . . . . . . . . . . 28

2.2.2 Generation of the ensemble forecasts . . . . . 29

2.2.3 System verification methods . . . . . . . . . 31

2.2.4 Illustration of the probabilities . . . . . . 33

2.3 Validation data . . . . . . . . . . . . . . . . 34

2.3.1 Observations . . . . . . . . . . . 34

2.3.2 3D hydrodynamic model data . . . . . . . 36 
3. Results 37

3.1 Hydrographical measurements . . . . . . . . . . 37

3.1.1 A general description of the hydrography in the Bothnian Sea . . . . . . . . . . . 37

3.1.2 Small-scale events . . . . . . . . . . . 39

3.1.3 Estimation of currents . . . . . . . . . 40

3.2 Monthly ensemble forecasts . . . . . . . . . . . . . . 43

3.2.1 Forecasting upwellings . . . . . . . . . . . 43

3.2.2 Forecasting harmful algal blooms . . . . . . . 43

3.2.3 Verification of the forecasting system . . . . . . 44

4. Discussion 49

4.1 The developments of the operational system . . . . . . . 49

4.1.1 Observational methods . . . . . . . . . . 51

4.1.2 The ensemble forecasting system . . . . . . . 52

$4.2 \quad$ Future work . . . . . . . . . . . . . . . . . 54

$\begin{array}{ll}\text { 5. Conclusions } & 57\end{array}$

$\begin{array}{ll}\text { References } & 59\end{array}$

$\begin{array}{ll}\text { Licences \& Permissions } & \mathbf{7 5}\end{array}$

$\begin{array}{ll}\text { Publications } & \mathbf{7 7}\end{array}$ 


\section{List of Publications}

This thesis consists of an overview and of the following publications which are referred to in the text by their Roman numerals.

I Simo Siiriä, Petra Roiha, Laura Tuomi, Tero Purokoski, Noora Haavisto and Pekka Alenius. Applying area-locked, shallow water Argo floats in Baltic Sea monitoring. Journal of Operational Oceanography, 1-15, doi:10.1080/1755876X.2018.15447832018.

II Noora Haavisto, Laura Tuomi, Petra Roiha, Simo-Matti Siiriä, Pekka Alenius and Tero Purokoski. Argo floats as a novel part of the monitoring the hydrography of the Bothnian Sea. Frontiers in Marine Science, 5:324, doi:10.3389/fmars.2018.00324, 2018.

III Petra Roiha, Simo-Matti Siiriä, Noora Haavisto, Pekka Alenius, Antti Westerlund and Tero Purokoski. Estimating currents from Argo trajectories in the Bothnian Sea, Baltic Sea. Frontiers in Marine Science , 5:308, doi:10.3389/fmars.2018.00308, 2018.

IV Petra Roiha, Antti Westerlund and Noora Haavisto. Forecasting upwelling events with monthly ensembles for the eastern coast of the Gulf of Bothnia in the Baltic Sea. Journal of Operational Oceanography, 9, 2, 115-125, 112016.

V Petra Roiha, Antti Westerlund, Aleksi Nummelin and Tapani Stipa. Ensemble forecasting of harmful algal blooms in the Baltic Sea. Journal of Marine Systems, 83, 3, 210-220, 112010. 
List of Publications 


\section{Author's Contribution}

Publication I: “Applying area-locked, shallow water Argo floats in Baltic Sea monitoring"

PR participated in designing the article, along with SS. SS wrote the first draft of the manuscript. PR analysed the case studies. TP was mainly responsible for operating the floats, and $\mathrm{NH}$ analysed the general float data. PA did most of the literature study with PR. LT instruct this work. Conclusions were reached through a common understanding and the final manuscript was accepted by all the authors.

\section{Publication II: "Argo floats as a novel part of the monitoring the hydrography of the Bothnian Sea"}

$\mathrm{NH}$ wrote the first draft with significant help from LT and held the main responsibility for the analysis of the observation data and production of the illustrations. PR, S-MS, LT, and PA contributed to the illustrations. Background research was mainly done by $\mathrm{NH}, \mathrm{PR}$, and PA. TP was responsible for the technical support and acquisition of data. All the authors contributed to the evaluation of the data, wrote sections for this manuscript, and revised and approved the sent version.

Publication III: "Estimating currents from Argo trajectories in the Bothnian Sea, Baltic Sea"

All the authors contributed to the design of this study. PR wrote the first draft and largely did the analyses for the observations and model results. S-MS and NH contributed to analyses and illustrations. PR, 
$\mathrm{NH}$ and PA did literature and background research. AW did the $3 \mathrm{D}$ modelling for this study and contributed to analysing the model results. TP participated significantly in the acquisition of the data and evaluation of the measurements with PR and NH. All the authors wrote sections for this manuscript, and revised and approved the sent version.

\section{Publication IV: "Forecasting upwelling events with monthly ensembles for the eastern coast of the Gulf of Bothnia in the Baltic Sea"}

PR had the main responsibility for outlining the article, conducting the analysis and reaching the conclusions with the other authors. PR also was responsible for writing the paper and managing the publication process. AW implemented the forecasting system, analysed the model and participated in the writing and in making conclusions. $\mathrm{NH}$ went through the tide gauge data and analysed the upwelling cases.

\section{Publication V: "Ensemble forecasting of harmful algal blooms in the Baltic Sea"}

PR had the main responsibility for outlining the article and conducting the analyses. PR was also responsible for the writing and handling the publication process. AW implemented the forecasting system and validated the model. AN analysed a case study and drew the figures. TS instructed this work. All the authors wrote parts of the manuscript, and the conclusions were made in common understanding with all the authors. 


\section{Introduction}

\subsection{Background}

\subsubsection{The Bothnian Sea and Eastern Gotland Basin}

The dynamics in the Baltic Sea are driven by topographical, meteorological and hydrological factors. The Baltic Sea is permanently stratified due to the facts that there is saline water entering the basin from the North Sea through the Danish straits and large amount of fresh water coming from the rivers. The Baltic Sea and its sub-basins, surrounding countries and drainage area are shown in Figure 1.1.

The layered structure of the water column restricts the wind's effect upon the upper layer, typically above the depth of $40-80$ metres. The upper layer and the lower layer are separated by the halocline. During the summer there is typically a well-mixed surface layer formed by heating and wind-induced mixing, that is typically between 15-20 metres deep. In the autumn this thermocline disappears due to thermal convection and turbulent mixing. Further information of the hydrography of the Baltic Sea can be found in the work of Leppäranta and Myrberg (2009)

In this study the focus is on two sub-basins: the Bothnian Sea and the Eastern Gotland Basin (Figure 1.1). The Gulf of Bothnia is the northernmost basin of the Baltic Sea and the Bothnian Sea is the southern part of the gulf. It is separated from the Åland Sea by a shallow sill so that the more saline bottom water from the Baltic Proper cannot enter the basin. 


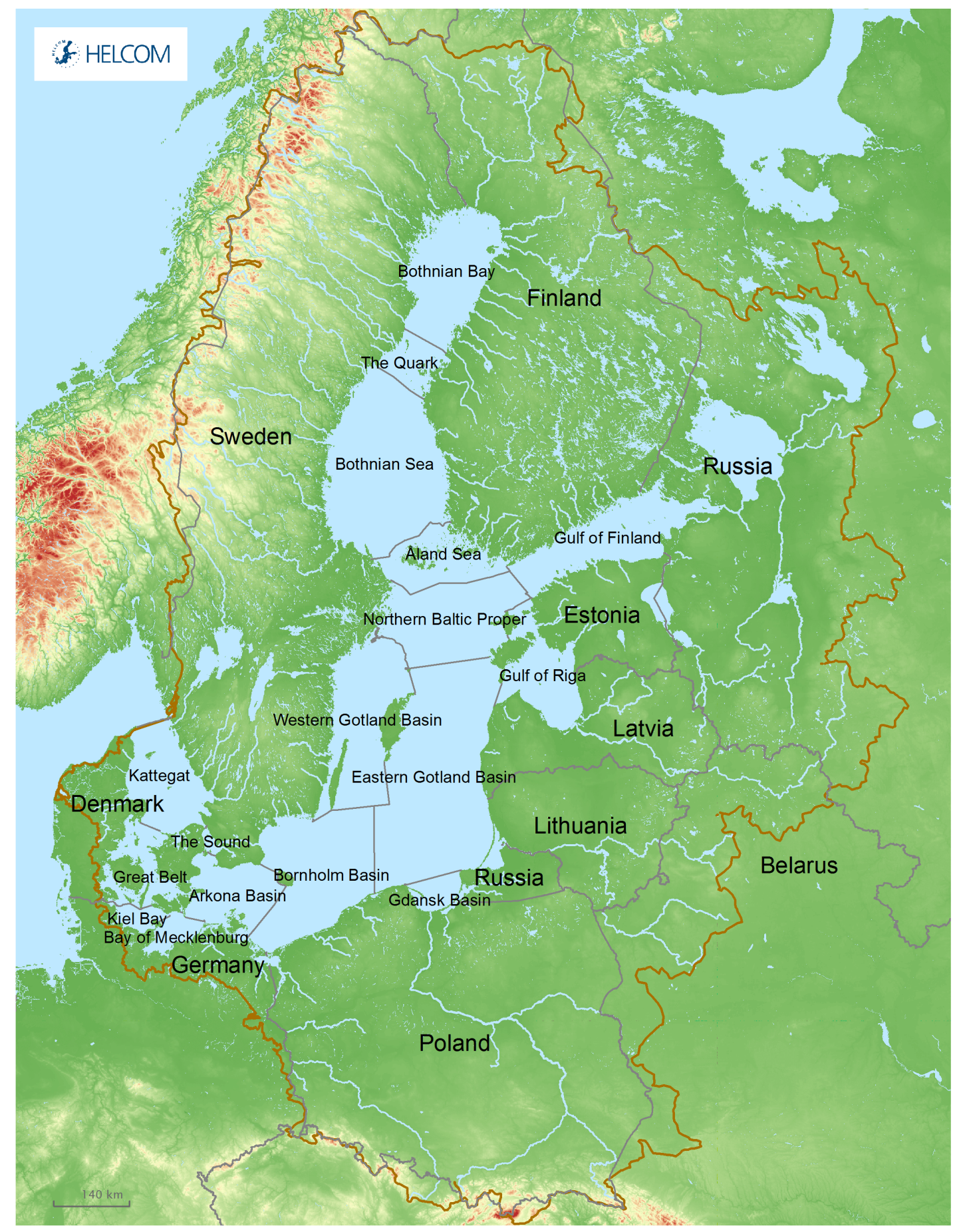

Figure 1.1 A map of the Baltic Sea sub-basins, surrounding countries and drainage area (HELCOM 2018b). 
In the north the Bothnian Sea and the Bothnian Bay are separated by the Quark. The maximum depth in the Bothnian Sea is 293 metres found in Ulvö Deep, near the Swedish Höga Kusten ("High Coast"). The mean depth is 66 metres.

The Eastern Gotland Basin is a part of the Baltic Proper. The southern mouth of the area is the Stolpe Channel. The northern line between the Eastern Gotland Basin and the Northern Gotland Basin is located along the line from Fårö to Gotska Sandö and Ristna. It is large bowl-shaped basin with a mean depth of 77 metres and a maximum depth of 249 metres in the Gotland Deep.

Coastal upwelling is a fairly common phenomenon in both basins (Lehmann et al. 2012). Harmful algal blooms (HAB) are more severe in the Baltic Proper (Rönnberg and Bonsdorff 2004) and the marine traffic is heavy (HELCOM 2018a). The Bothnian Sea, on the other hand, is less saline with shallower mean depth, and parts of it freezes over the course of an average winter (Leppäranta and Myrberg 2009).

In general, the deep-water oxygen conditions in the Bothnian Sea are fair or better and the hydrographical conditions support this state. However, with profound changes in the hydrographic regime or an increase in anthropogenic loads, hypoxic conditions may occur (Raateoja 2013). In the Baltic Sea in general, the ecological food web is affected by environmental factors and human influence (Österblom et al. 2007). The long-term changes in the Bothnian Sea food web were studied closely by Kuosa et al. (2017). They found out that the recent changes in deep-water intrusion from the Baltic Proper affect salinity and the stratification. This in turn has an effect on the structure of the phyto- and zooplankton communities.

In the Baltic Proper algal blooms have been a fairly common phenomenon due to the anoxic conditions in the bottom of the sea, where phosphate is released first into the deep water and from there to the surface water. A high phosphate concentration is a prerequisite for the nitrogen-fixing cyanobacteria that cause the summer blooms, but the local weather conditions also play a crucial role (Bianchi et al. 2000, Raateoja et al. 2011).

In contrast to the Baltic Proper, HABs have been fairly rare in the Gulf of Bothnia, partly because the oxygen situation in the bottom is fair. Apparently, in recent years the nutrient situation has been changing in favour of harmful algae (Jaanus et al. 2011). The hypothesis is that phosphorus 


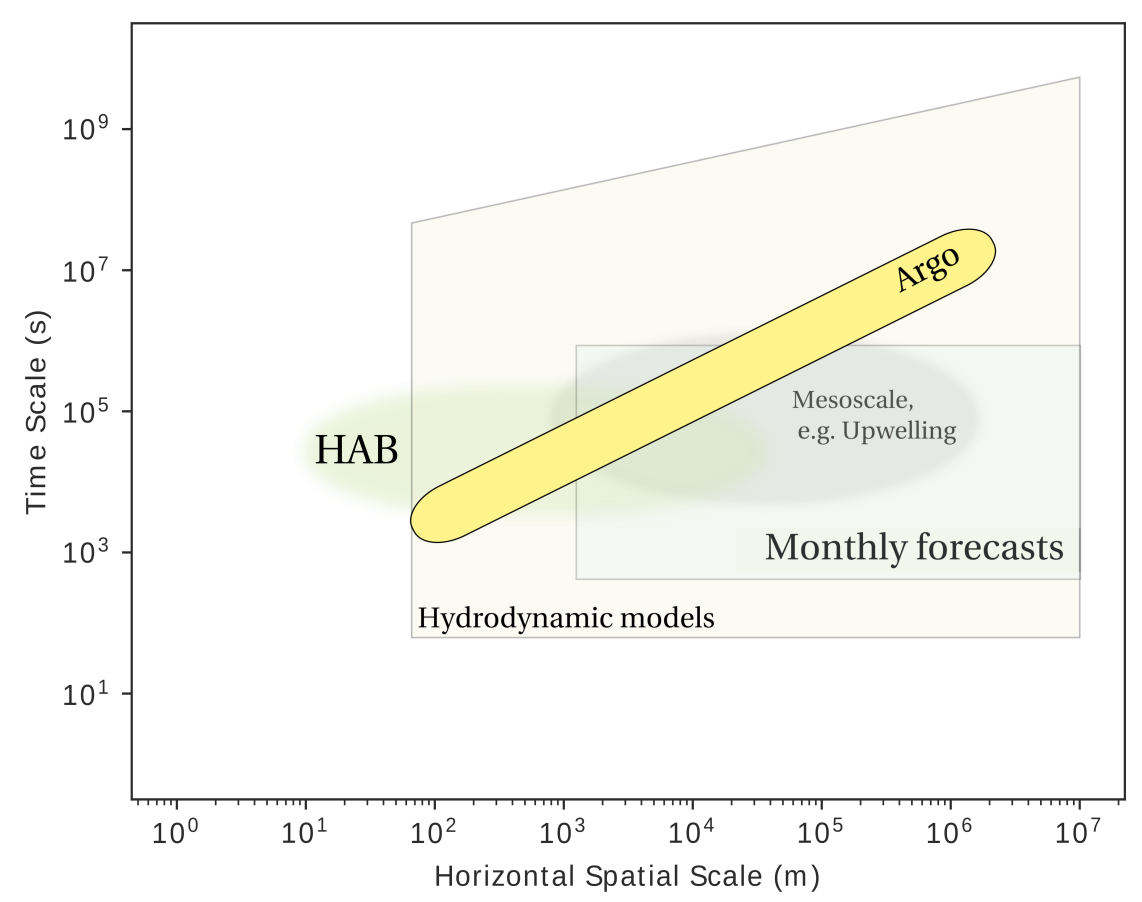

Figure 1.2 Spatial and temporal scales in the sea. Figure after Stommel (1963) and Dickey (2003).

rich water is entering the Bothnian Bay from the Baltic Proper, making nutrients available for algae. (Rolff and Elfwing 2015).

The changes in the climate will affect the Baltic Sea as well. The warming trend can be already seen and it will continue in the future (BACC II and Author Team 2015). The effects of the climate change can be modelled and projected and on-going observations are essential to be able to make well-informed decisions (Andersson et al. 2015).

In the following section the studied phenomena are described more closely.

Spatial and temporal scales in the sea

In this study the focus was on physical and biochemical phenomena, which are closely related and have an effect on the marine environment and regional climate. Measurements focused on temperature, salinity, oxygen concentration and currents. The forecasting methods focused on upwellings and HABs. With the current methods we are not fully able to understand and measure the crucial phenomena that take place on the mesoscale and submesoscale. 
The mesoscale embeds the range of marine features that span from tens to hundreds of kilometres and has time scales ranging from days to weeks (See Figure 1.2). In the Baltic Sea the range of the mesoscale is typically from $5 \mathrm{~km}$ to $20 \mathrm{~km}$ and it depends on wind forcing as well as buoyancy forcing. Many of the currents, fronts and eddies take place on this spatial and temporal scale. In particular, many chemical and biological processes take place on the mesoscale (McGillicuddy 2016) and submesoscale (Lévy et al. 2012). In the climatological scale, homogenous area for the Baltic Sea water masses was defined by Haapala and Alenius (1994) to be $30^{\prime} \times 1^{\circ}$ or $55 \mathrm{~km} \times 55 \mathrm{~km}$ (latitude $\times$ longitude).

The mesoscale can be numerically defined by the internal Rossby radius. The Rossby radius is basically the horizontal scale at which the earth's rotation effects become as important as buoyancy effects (Gill 1982, Ch. 7.7.5 The Rossby Radius of Deformation). It varies with latitude, basin depth and regional and seasonal variations in stratification. The Baltic Sea is located in latitudes where the wind forcing is strong. The changes in the stratification and the wind conditions cause the mesoscale to have a large variance within the Baltic Sea. The smallest Rossby radius values are found in the Belt Sea and the Gulf of Finland in autumn (1.3-2 km) (Fennel et al. 1991, Alenius et al. 2003) and the largest values are found in the Gotland Deep (11.9 km) (Alenius et al. 2003). The Bothnian Sea was not considered in the aforementioned studies. An estimate of the internal Rossby radius scale in the Bothnian Sea was presented by Westerlund and Tuomi (2016); they provided an expert estimation of the radius to be $2-5 \mathrm{~km}$. In this work the focus is in mesoscale and it is defined as presented above. There are other definitions for mesoscale and atmospheric scientists regognise also sub-categories. Sub-mesoscale and large scale are mentioned in the meaning of smaller and larger scales than the mesoscale, respectively.

As seen in Figure 1.2, it is possible to measure and forecast the aforementioned scales to some extent, but further studies are still needed. The spatial resolution with the monthly forecasts in this study is $6 \mathrm{NM}$ and the forecasted area is the Baltic Sea (see Section 2.2.1). The temporal resolution for the monthly forecasts is in an order of days. This resolution covers most of the mesoscale phenomena. More advanced hydrodynamic modelling systems can theoretically reach as high spatial resolution as that of an order of metres and range up to a global scale. In general, global 
models have lower resolution than the local models due to the limited computational and storage capasity of modern computers. In practice, the model run is a compromise between time span, size of modelled area and spatio-temporal resolution.

In this work the Baltic Sea Argo floats were used. The measurements can reach a spatial resolution ranging from hundreds of metres to kilometres and the range of the mission can extend up to hundreds of kilometres. The temporal resolution of Argo floats is at best in the order of hours and the range of the mission can be on a yearly scale (see Section 2.1). Argo floats fill spatial and temporal gaps in observational network (Table 1.1).

The interconnection between physics and biology is tight knit: the currents, temperature and salinity have a crucial effect on life in the sea, providing and changing the availability of energy and nutrients for the living organisms (Stigebrandt 2001). The nutrient and carbon cycles depend heavily on temperature. The oxygen conditions can change drastically in time scales ranging from hours to weeks (Viktorsson et al. 2012) and nutrient concentrations have large spatial and temporal differences between sub-basins and between stations within the sub-basins (Sandén and Danielsson 1995). The optimisation of the monitoring station locations for temperature, salinity and nutrient concentrations was analysed in the Baltic Proper by Toompuu and Wulff (1996).

\section{The temperature and salinity structure}

Leppäranta and Myrberg (2009) defined that hydrography characterises the physical and chemical properties of the water column and circulation using empirical methods. Commonly this includes temperature, salinity, pressure and density, alongside some chemical properties such as oxygen concentration, nutrients and turbidity. The temperature and salinity, among other variables, have a great effect on the life of the sea and understanding the air-sea interaction.

The water column structure in the Bothnian Sea is two layered in vertical direction with a weak halocline at the depth of 50-60 metres. The saline water in the bottom originates from the surface water of the Baltic Proper, entering the Bothnian Sea through the Archipelago Sea and Alland Sea (Marmefelt and Omstedt 1993). The maximum salinity in the bottom is 6-7. In the summertime the thermocline forms at the depth of 15 metres 


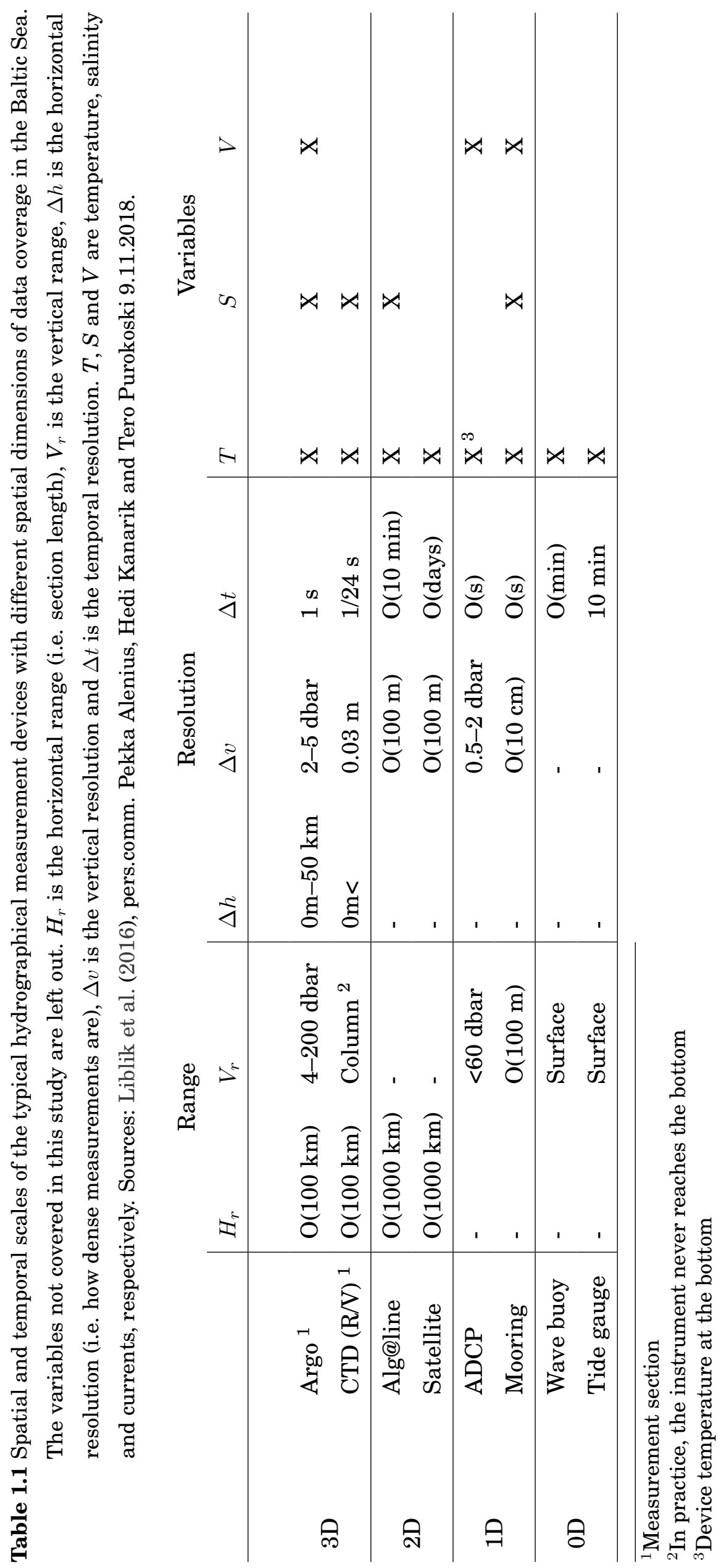


on average. The mean horizontal circulation in the north-south direction takes place in the surface layer in cyclonic motion. The wind forcing has a strong effect on the currents, especially at the surface, which causes the strong variation in the current field (Håkansson et al. 1996).

The water column in the Baltic Proper is strongly stratified and the maximum salinity at the depth of 200 meters can be up to 13 . The bottom water is only ventilated by incoming water pulses from the North Sea. The biggest pulses are called major Baltic Inflows (MBIs), which have been registered since 1887 (Mohrholz 2018); the latest incoming large MBI was detected in 2014 (Mohrholz et al. 2015).

\section{Currents}

Surface currents have been an important factor in the seafaring in the Baltic Sea. The first continuous current measurements in the northern Baltic Sea were made from lightships at the end of the19th century (Mälkki 2001). Witting (1912) was the first to study the surface currents in the Bothnian Sea. Palmén (1930) formulated the first concept of the cyclonic surface current field in the Finnish sea areas based on the lightship observations. Later, Hela (1958) studied the currents in the upper layers and hydrography in the Bothnian Sea. The year 1991 was the Bothnian Sea Year and an extensive measurement campaign on currents was launched, both on surface currents (Uotila et al. 1995) and on currents in water column (Alenius 1993). Only in recent years, after the era of lightships, have the long-term measurements with acoustic Doppler current profilers (ADCPs) and moorings been started. In the deep sea areas, the availability of the data is still heavily dependent on the occurrence of measurement campaigns.

The currents are induced in the Baltic Sea with different mechanisms. The most important are surface wind stress, sea surface tilt (due to the wind or air pressure gradient), thermohaline horizontal density gradient and potential tidal forces. The currents are further affected by friction, local topography and Coriolis force. More information on currents can be found, for example, in Leppäranta and Myrberg (2009).

Currents are an important factor for transporting momentum, energy and matter and affecting turbulence in marine environment. The bottom currents cause friction and affect suspension and resuspension of sediments. Locally, for example, the river run-off can change the sea level and thus 
have an effect on the currents. Also, the weather phenomena, such as strong winds and low pressure cells, can tilt the sea surface and cause seiches. In the Bothnian Sea basin the seiche period is in the order of hours, estimated by using the Merian formula (Lisitzin 1974).

\section{Upwelling}

The upwelling phenomenon is a fairly common event in the Baltic Sea (Myrberg and Andrejev 2003, Lehmann et al. 2012, Lehmann and Myrberg 2008). Strong enough winds frequently cause an upwelling somewhere in the Baltic Sea. The wind event must last at least 60 hours, and the wind direction and water column stratification play important roles: when the stratification is strong (in summer time) the wind impulse needed to cause upwelling is much smaller than when the water column is homogenous (Haapala 1994). The atmospheric conditions leading to an up- or downwelling in the Baltic Sea were studied on a large scale by Lehmann et al. (2001), who analysed the effects of the North Atlantic Oscillation on upand downwelling events.

The Bothnian Sea has favourable conditions for the occurrences of upwelling phenomena (Myrberg and Andrejev 2003). When the northerly wind's direction runs along the coast on the right-hand side of the basin, the sea level rises and on the other side it falls due to Ekman transport. Consequently, coastal jets on the both sides of the basin emerge and the coastal water is then replaced slowly with water from the central basin (Krauss and Brügge 1990).

In the Baltic Proper the surroundings of the Gotland Island have a pronounced up- and downwelling system. The south-westerly winds cause upwellings on the east coast of the island and downwellings on the western coast. The width of the upwelling zone is $10-20 \mathrm{~km}$ and the length is around $150 \mathrm{~km}$ (Myrberg and Andrejev 2003).

The upwelling characteristics in the Baltic Sea have been studied with different methods. Ferryboxes crossing the Gulf of Finland have been used to analyse the upwelling features (see, e.g. Kikas and Lips 2016). Satellite sea surface temperature (SST) analysis of upwelling events was made by Kahru et al. (1995) with the Advanced Very High Resolution Radiometer (AVHRR) instrument and by Uiboupin et al. (2012) using Moderate Resolution Imaging Spectroradiometer (MODIS) data and Chl- $a$ with MEdium Resolution Imaging Spectrometer (MERIS) data. Myrberg 
and Andrejev (2003) modelled and analysed statistically the upwellings with the Oleg Andrejev-Alexander Sokolov (OAAS) model (Andrejev et al. 2004), and Kowalewski and Ostrowski (2005) studied up- and downwelling events on the southern coast of the Baltic Sea with the Princeton Ocean Model (POM).

The importance of the upwelling phenomenon is that it lifts cold and nutrient-rich water to the near surface (euphotic) layer, where it can be used by biological processes. This has an effect on physical and chemical patterns (Lips et al. 2009) and eventually on the ecosystems and therefore, for example, on algal blooms (Vahtera et al. 2005, Zhurbas et al. 2008, Lips and Lips 2008).

In the Baltic Sea, the upwelling phenomenon may play a key role in replenishing the nutrients necessary for the biological activity later in the summer when the amount of nutrients is diminished in the euphotic zone. In the areas where upwelling lifts phosphorus-rich water, the nitrogenphosphorus (N/P) ratio becomes small, favouring potentially harmful, nitrogen-fixing blue-green algae (Lehmann and Myrberg 2008, Vahtera et al. 2010, Wasmund et al. 2012). The upwellings may also have an effect on the reproductivity of fish by changing temperature and salinity conditions (Nissling et al. 2006). The upwellings affect the lower boundary layer of the atmosphere (Sproson and Sahlée 2014). The cold water can cause fog formation in very local coastal areas (Leppäranta and Myrberg 2009). The rapid fog formation is difficult to forecasts without understanding the dynamics of the sea. The upwelling phenomenon has an impact on the $\mathrm{CO}_{2}$ balance between air and sea (Krapivin and Varotsos 2016). The frequent upwellings in the Baltic Sea are expected to have a major impact on the Baltic Sea carbon budget (Norman et al. 2013). Globally, the upwelled, $\mathrm{CO}_{2}$-enriched waters, can have an impact on shallow water ecosystems (Melzner et al. 2013).

\section{Harmful algal blooms}

The history of algal bloom studies in the Baltic Sea begins at the end of the 19th century (Finni et al. 2001). In early studies, the algal bloom observations were from coastal areas, and systematic recordings from the open ocean started after the World War II. Since the 1960s cyanobacterial blooms have been frequent in the Gulf of Finland and Baltic Proper, which indicates abundant nutrient availability. Groetsch et al. (2016) concluded 
that the spring blooms in the Baltic Sea have weakened but lengthened from the year 2000 to 2014 .

Eutrophication is one important factor that increases the number of algal blooms. In the Baltic Sea the trend for eutrophication has been growing in the 112-year period and a large part of the Baltic Sea is classified as "affected by eutrophication" (Andersen et al. 2017). Eutrophication is the main culprit for many environmental issues in the Baltic Sea, including the blooming of harmful algae (Heisler et al. 2008). Basically, the more nutrients that are available, the more algal blooms. In the Baltic Sea, the intensity of spring blooms seems to have reduced from 2000 to 2014 due to the reductions in nutrient loading (HELCOM 2018b). However, in the Bothnian Sea the amount of harmful algal blooms has increased, which is in connection with an increase in phosphate concentrations (Korpinen et al. 2018).

The relation between the phosphorus concentration and cyanobacterial blooms was recognised four decades ago (Niemi 1979). This known relationship has been utilized in practical and operational uses. However, the weather additionally controls how the algae situation develops in the end. The effect of atmospheric forcing on the nutrient availability was studied in the Baltic Sea by, for example, Lehtoranta et al. (2017) who concluded that the nutrient inputs to the Gulf of Finland cannot explain the inter-annual variation of the nutrient pools and that they are related to the atmospheric conditions and stratification of the water column.

The difficulty in forecasting the algal situation and blooms can be demonstrated by a contemporary examplefrom the sea areas surrounding Finland: in the beginning of June 2018, the assessment of the number of algae blooms predicted a lower risk of blooms than earlier years (SYKE 2018a). However, the exceptionally warm weather increased the algal growth so that the algal blooms were the strongest of the 2010's and at the largest the blooms covered almost the whole of the Gulf of Finland, as well as the southern parts of the Archipelago Sea and Åland Sea (SYKE 2018b).

\subsubsection{Operational oceanography and marine management}

The first interesting marine phenomena for the seafaring were waves, tides and currents as they were crucial elements for people living by the shore and getting their livelihood from the sea. 


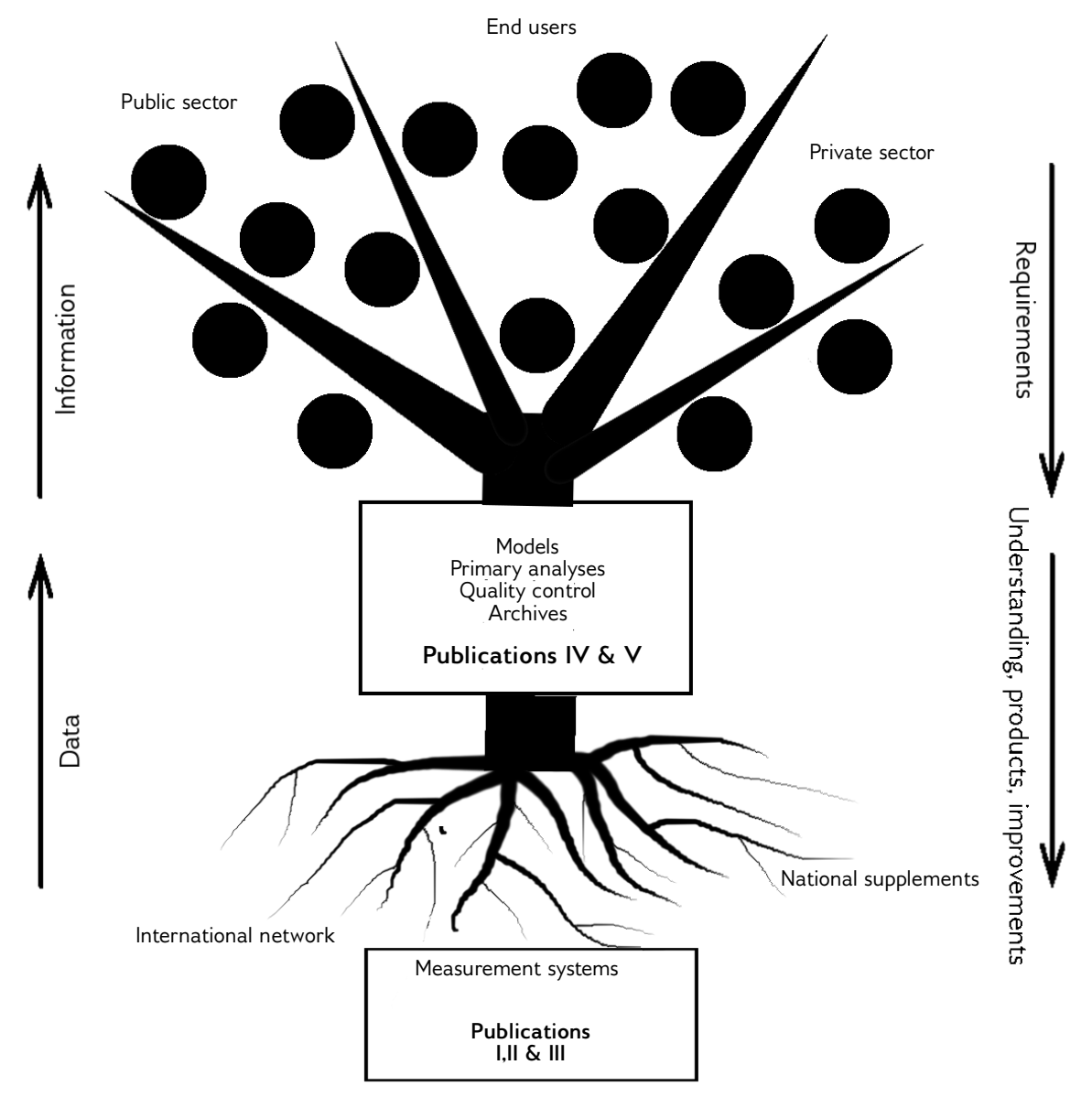

Figure 1.3 An outline of the operational oceanographic system (simplified and modified from Bell et al. (2013)). The publications included in this thesis and the main areas of studies are marked on the picture. 
During the Age of Discovery (1400-1700) the ocean explorations were mainly cartographic and surface observations. The first scientific voyages were made in the late $1700 \mathrm{~s}$. At the same time, the first hydrographic measurements in the Baltic Sea were carried out (Fonselius and Valderrama 2003). World War II had a major effect on the development of the first wave forecasts and thus it gave the first push to the development of the operational oceanography (Schiller and Brassington 2011).

Operational oceanography is a multi-disciplinary branch of science that aims to benefit many aspects of society (Figure 1.3). However, there is no single definition of operational oceanography. One description is given by Flemming (2002) as follows:

Operational oceanography is the provision of scientifically based information and forecasts about the state of the sea (including its chemical and biological components) on a routine basis, and with sufficient speed, such that users can act on the information and make decisions before the relevant conditions have changed significantly, or become unpredictable. (Flemming 2002).

To be operational, the service needs to be real time, and routinely and robustly delivered. The services can include ocean observations, along with nowcasts and forecasts of different lengths. Usually the main difference from the scientific state of the art is the demand of robustness, limitation of computational capacity and real-timeliness. Robustness of the operational models commonly means that model versions are older than the state-ofthe-art, but more tested and reliable in operational environment.

The need to understand and forecast the conditions in the ocean has a long history, but one important breaking point in modern times was the Rio Conference Earth Summit in 1992 and the publication of Agenda 21 (Sitarz 1993), which emphasises the meaning of the oceans and predicting the ocean state (Pinardi and Woods 2002).

The operational marine systems helped to mitigate the effects of several disasters globally in the 2010s: Deepwater horizon oil spill in the Gulf of Mexico in 2010 (Liu et al. 2011), the Fukushima Dai-ichi nuclear power plant accident in Japan in 2011 (Tsumune et al. 2012) and the grounding of Costa Concordia on the shore of Italy in 2012 (Dominicis et al. 2014), to name but a few. 
The state of the Baltic Sea is monitored and managed both internationally and nationally. International politics have also greatly shaped the environmental protection of the Baltic Sea and the establishment of the Helsinki Commission (HELCOM) (Räsänen and Laakkonen 2007). During the 40 years of HELCOM, the loads from many pollution sources have decreased but many problems still exist (Elmgren et al. 2015).

At the international level, the EU Marine Strategy Framework Directive (MSFD; Directive 2008/56/EC; European Parliament and Council (2008)) has had a guiding effect on the national marine strategy. The ecological indicators are constantly developed to describe the environmental status and the goal is to eventually reach a Good Environmental Status (GES) in 2020 (see, e.g. Fleming-Lehtinen et al. 2015). The Finnish Marine Strategy Plan is composed of three parts, namely: "The State of the Baltic Sea" (Korpinen et al. 2018), "The Baltic Sea Monitoring Programme” (Korpinen et al. 2015) and "The Marine Management Action Plan" (Laamanen 2016). The national report of the state of the Baltic Sea is closely related to the international HELCOM report (HELCOM 2018b).

The other legislation affecting operational oceanography in Finland is the law "Laki Ilmatieteen laitoksesta" (212/2018), which defines that the Finnish Meteorological Institute (FMI) should advance physical oceanography. More precisely, it is obliged to warn citizens of hazardous situations in the sea; FMI is responsible for maintaining and delivering marine forecasts and develops new observational and modelling methods for marine services and for scientific purposes. The aims of these services could be, for example, predicting events that may threaten life, safety or security, or events that affect the marine health (Schiller and Brassington 2011). These services could also be used as a tool in marine spatial planning (MSP; Ehler and Douvere 2009).

The Finnish Marine Research Infrastructure (FINMARI) combines the national marine research infrastructure together. This covers, for example, research vessels and institutes, and also the Argo floats and other offshore observational platforms. Finland is also a founding member of the Euro-Argo European Research Infrastructure Consortium (ERIC), which is responsible for the overall coordination of Euro-Argo (Finnish Research Infrastructure Committee 2013). 
In Finland oceanographic research began with sea-level studies, ice studies and studies of water masses and hydrography (Mälkki 2001). Today, there are operational water-level measurements from 14 tide gauges along the Finnish coast, and there are wave data available from wave buoys during the ice-free season from the Gulf of Finland, the Baltic Proper and the Gulf of Bothnia. The Alg@line project measures the surface data from commercial ships in the Gulf of Finland and the Gulf of Bothnia. Several Argo floats send hydrographical data from the Baltic Proper, the Bothnian Sea and the Bothnian Bay.

In Finnish sea areas, the currently used operational models are hydrodynamic 3D model, the wave forecast model, the ice model and the water-level forecasts. Also, the Copernicus marine environment monitoring service (CMEMS) is making operational products for the Baltic Sea. There are other operational systems studies on the Northern Baltic Sea's water level and currents. For example, Lagemaa (2012) and Lips et al. (2016) studied sub-mesoscale fetures with models and multiple sensors, and Nowicki et al. (2019) studied upwellings in the southern Batic Sea.

Tonani et al. (2015) and She et al. (2016) analysed the future needs of the operational systems. Important developments that are needed are a higher model grid resolution, the development of a biogeochemical model coupled with a physical system, a coupled ocean-ice-wave-atmosphere forecasting system and improved data-assimilation systems. They also pointed out that ensemble approach in the operational forecasts should be studied further.

\subsubsection{Argo floats}

Argo floats are free-floating, autonomous ocean measurement devices, which can carry a variety of sensors and operate in distant sea areas for extended periods of time. There is a satellite connection to the float; some floats have a two-way Iridium satellite connection and they can send measured data in real time to the data centre. Argo missions can also be altered via satellite and floats can be recovered at the end of their mission if they are somewhat near the coast. 
Thompson et al. (2017) concluded that in the future, the ocean observing systems need to be heavily autonomous in order to be able to achieve temporally and spatially dense measurement coverage of a high quality. The mission planning should be developed so that it can autonomously determine the sampling directives based on the observations from the water column, models and remote sensing. The interplay between physical circulation and biogeochemical cycles is of great interest. With the currently existing methods they are captured occasionally.

\section{The Argo project}

The Argo project (Roemmich et al. 2001) was the first project to collect a vast global data set from the upper layer of the ocean $(<2000 \mathrm{~m})$. Initially, the Argo floats collected salinity and temperature data to assess the signals of the climate change. Since then the Argo technology has matured and the variety of the sensors has also increased (Riser et al. 2016). Currently there are three models of Argos in use: PROVOR built by KANNAD (France), Autonomous Profiling Explorer (APEX) built by Teledyne-Webb Research Corporation (USA) and the SOLO float built by the Scripps Institution of Oceanography (USA) (Thomson and Emery 2014). In this study only the APEX floats were used.

Nowadays all Argo floats are equipped with salinity, temperature and pressure sensors (Gould et al. 2004) but the amount of additional sensors for Argo floats has grown (Johnson et al. 2009), including sensors for oxygen (Körtzinger et al. 2004), for pH (for analysing $\mathrm{pCO}_{2}$ ) (Williams et al. 2017), for fluorescence and turbidity (Boss et al. 2008) and for chlorophyll-a (Xing et al. 2011) to name but a few.

In the northern latitudes, and thus, also in the Baltic Sea, ice is an important environmental factor affecting Argo missions. The risk of colliding while surfacing or being stuck in the middle of ice is real. However, methods for measuring under ice have been developed and data has become available from ice-covered areas (Klatt et al. 2007, Wong and Riser 2011).

Nowadays the Argo data is used in climate studies and it has revealed the ongoing heating in the deep oceans (Roemmich et al. 2015, von Schuckmann et al. 2016) and marginal seas (Schroeder et al. 2017) along with potential changes in chemistry and biology (Howes et al. 2015). Argo floats have brought more information, especially about the world ocean's heat 
storage, and thus helped to understand the energy balance and the climate change, as well as variability of the temperature and salinity in the world's oceans (Ninove et al. 2016).

The Argo project has also had a great impact on ocean forecasting and it has become a crucial part of developing links from seasonal to decadal predictions (Le Traon 2013).

\subsubsection{Hydrodynamic modelling and forecasting}

The 3D models used in operational oceanography solve the Navier-Stokes equations for a thin layer on a rotating planet. The equations may be simplified in several ways and certain assumptions may be introduced (incompressibility, hydrostatics). Models that solve these equations are called ocean general circulation models (OGCMs) (Schiller and Brassington 2011). The Baltic Sea has been extensively modelled by different models in the 2000s. To name some examples, Myrberg and Andrejev (2003) studied main upwelling regions in the Baltic Sea with the OAAS model, Meier (2001) studied mixing in the Baltic Sea and Meier et al. (2006) deep water ventilation with the Rossby Centre Ocean model (RCO). Tuomi et al. (2012) studied mixing in the Baltic Sea with COHERENS model (Luyten et al. 1999). Burchard et al. (2009) studied bottom currents in the western Baltic Sea and Holtermann et al. (2014) studied deep water dynamics and mixing in a stratified basin in the Baltic Sea with the General Estuarine Transport Model (GETM) (Burchard et al. 2004). The Nucleus for European Modelling of the Ocean (NEMO) model (Madec and the NEMO team 2008) has been used in the Baltic Sea (Hordoir et al. 2013, 2018). Westerlund and Tuomi (2016) used NEMO to analyse mixing in the northern Baltic Sea.

In the Baltic Sea there are some specific challenges in modelling. In general, the weather forcing has large impact on the results from ocean models (Treguier et al. 2017). In the Baltic Sea, the issue was discussed by, for example, Tuomi (2014) and Westerlund (2018). The weather forcing has to be selected carefully and with sufficient resolution, but oftentimes a forcing with sufficient resolution is not available. The river input is also a dominant feature in the hydrography and its modelling appears to be difficult (Placke et al. 2018). Also, to be able to describe mesoscale phenomena correctly, there is need for a sufficiently high horizontal resolution. 


\section{Ensemble forecasts}

Forecasting is always coping with uncertainties. The errors are everywhere, ranging from being in observations to being in model setup and code, parameters and interpretation of the data. Moreover, the effect of small errors tends to grow in time when the forecast length increases (Lorenz 1965). To be able to estimate the range of possibilities the estimation of the errors in the system is needed (Leutbecher and Palmer 2008). Treguier et al. (2017) concluded that "the next frontier" regarding the mesoscale forecasts is the systematic use of ensemble approaches, as already used in the weather forecasting and climate scenarios because of the chaotic nature of the mesoscale phenomena.

The ensemble forecasting methods are developed from the Monte Carlo techniques (Metropolis and Ulam 1949). One possibility is to produce several forecasts instead of one deterministic forecast so that it is possible to see the range in which the true result lies. This requires more computational power and different analysis methods.

Ensemble forecasts can be formed with different methods: by running a model with different forcings (e.g. Molteni et al. 1996), by combining multiple ensembles for multi-model multi-analysis ensembles (e.g. Mylne et al. 2002) or by combining the ensemble from different deterministic forecasts (e.g. Ebert 2001). Operational multi-model ensembles for nowcasting exist for the Baltic Sea (Golbeck et al. 2015). The multi-model ensembles for management needs in the Baltic Sea in particular have been under development during this decade (see, e.g. Meier et al. 2014).

The interpretation of the ensemble forecasts is not as straightforward as with deterministic forecasts and specialised methods for interpreting uncertainties have been developed.

The uses for ensemble forecasts are numerous, ranging from marine resources management (Hobday et al. 2016) and operational forecasting (Golbeck et al. 2015) to planning autonomous glider paths during mission (Wang et al. 2013) and weather-scale ice forecasting (Mohammadi-Aragh et al. 2018).

For decision-making, forecasts of different length are of great importance. For example, Hobday et al. (2016) analysed the different lengths of forecasts that are important for decision-making concerning fisheries. Middlerange forecasts (7-10 days) are needed for reactive management, such as 
farm maintenance and feeding cycles. Seasonal-scale forecasting (weeks to months) provides an early window for implementing strategies to minimize impacts, for example, for labor needs and harvest time. Monthly forecasts are also used for navigation and route planning in ice (Choi et al. 2015). Climate projections (covering decades to centuries) are used as part of long-term planning tools, for example, for MSP and marine infrastructure.

Climatological multi-model ensembles can be used in the Baltic Sea for estimating the water level (Johansson et al. 2014) and flood risks (Särkkä et al. 2017, Pellikka et al. 2018) over the scale of decennials. Climatological ensembles have been used also in the estimation of sea ice cover (Karpechko et al. 2015)

\subsection{The Research Gap}

Operational oceanography is a fast-developing multi-discipline branch of science that aims to offer tools for better marine management.

The need to understand marine system ecology is rooted in the Rio Climate Conference 1992 (see Section 1.1.2). Other tasks for operational oceanography are to fulfill the management needs to ensure economical, security and safety issues in the marine environment. Siedlecki et al. (2016) recognised the need for developing scientific methods to improve regional predictability in time scales ranging up to the seasonal scale.

To understand the state of the sea the observations are needed. Until the present, the amount of ocean observation has been very small and it has not been possible to study and observe the state of the sea as often and widely as necessary for mesoscale studies.

In general, it is possible to take measurements near the shore fairly often, but for example, in the Bothnian Sea, the hydrographical monitoring is conducted on average four times a year on COMBINE cruises (see Section 2.3.1). With this measurement frequency it is possible that the extremes in the hydrography remain unseen. Knowing the extreme values and changes in physical conditions is important. With understanding of the physics it is possible to analyse, for example, the effects on changes in ecology or gas exchange between the sea and air. The methods for capturing those values should be studied further. 
The need for understanding processes in the ocean and reacting against unwanted changes in advance is important in marine management. The marine management decisions need different information and forecast scales depending of the nature of the task at hand. For example, Operational ensemble HAB forecasts on monthly scale have not been available before for the northern Baltic Sea. In this study, the monthly scale ensemble forecasts are developed to better understand the upwelling phenomena and analyse the feasibility of forecasts of different lengths. The HAB forecasts on a monthly scale are developed to add information on the timing and location of potential algae blooming.

\subsection{Objectives}

Operational oceanography has the broad aim of bringing the best interdisciplinary knowledge achievable to people who need tools for well-informed decision-making.

In this thesis, two important areas of operational oceanography are studied and their methods are improved: measurement systems and forecasts produced with $3 \mathrm{D}$ models. New observational methods are developed further, as are the methods for analysing the data (Figure 1.3). The monthly ensemble forecasting methods are also developed and the results and performance are analysed.

The appended publications are organised so that the first three publications are more in the field of descriptive oceanography and the development of observational methods and data analysis. The latter two are from the field of computational oceanography and forecasting.

The solid basis of marine science is formed of the observations, so this work begins with measurements and their analyses (Publications I-III). The forecasting methods are analysed in Publications IV and V.

The publications with Argo observations bring us new knowledge about the present state of the sea on a spatio-temporal scale that have been missing so far in certain areas. In Publication I, the usability and piloting of the floats in the shallow seas is discussed. In Publication II the comparison with traditional methods is shown and methods for extracting more data from measurements are studied. In Publication III the methods for extracting and analysing the data from GPS information are developed 
further.

Ensemble predictions brings us more understanding of the future state of the sea; the future needs for these kind of forecasts were described by Hobday et al. (2016) and Tonani et al. (2015). In Publication IV the ability to forecast upwelling phenomena over an extended period of time is discussed.

With Publication V, the subject of how to make the forecasts and their uncertainties understandable for a layperson or decision maker is touched upon. The approach discussed in this publication was also covered in the work of Flynn and McGillicuddy (2018).

This thesis addresses the key questions concerning the research problem of improving the operational system for describing and predicting ecologically and environmentally substantial phenomena:

- How can observational data can be collected and analysed with new methods in order to improve temporal and spatial coverage? (Publications I-III)

- What kind of phenomena can be forecasted well in advance, even within a time scale of weeks? (Publications IV and V)

More specifically, we can divide these questions into smaller subareas with the following objectives:

1. utilise the new autonomous measuring devices and analysis methods in the Baltic Sea - on temporal and spatial scales - filling the gap in the existing observational network.

2. develop new methods to extract additional current information from Argo measurements

3. explore the limits of the predictability of the upwelling phenomenon in the Bothnian Sea

4. evaluate the feasibility of ocean ensemble forecasts predicting HABs and upwellings in the Baltic Sea 
Introduction 


\section{Materials and Methods}

\subsection{Argo floats in the Baltic Sea}

In Publications I, II and III, the piloting of the floats, hydrography and currents was analysed for the first time from the Argo float data from the Bothnian Sea and the Eastern Gotland Basin. In oceans the floats measure profiles from 1000-2000 metres depth and their diving cycle is 10 days. For the Baltic Sea the diving depth is around 100-200 metres and the diving cycle is 1-7 days. A schematic description of the floats' measuring cycle is presented in Figure 2.1.

The special characteristics of the Baltic Sea make the float measurements different to their operation in the oceans. The sea is shallow and the diving settings and the balancing of the float must be adjusted to selected sub-basins because of the brackish water and differences in the salinity. This affects water density and therefore floats' buoyancy. Many areas of the sea are heavily trafficked and therefore the risk of collision while surfacing exists. The northern parts are ice covered during the cold season so ice avoidance is essential for the measurement campaigns lasting over winter.

The Argo floats in the Baltic Sea have temperature, salinity and pressure sensors. Some of them also measure fluorescence and oxygen concentrations. The routes of the missions are shown in Figure 2.2 and the technical details of the floats are described in Table 2.1.

Argo data is first processed and real-time quality controlled by national Data Assembly Centers (DACs) before being sent to the Global Data Assembly Center (GDAC). In general, Argo data is quality controlled in two 


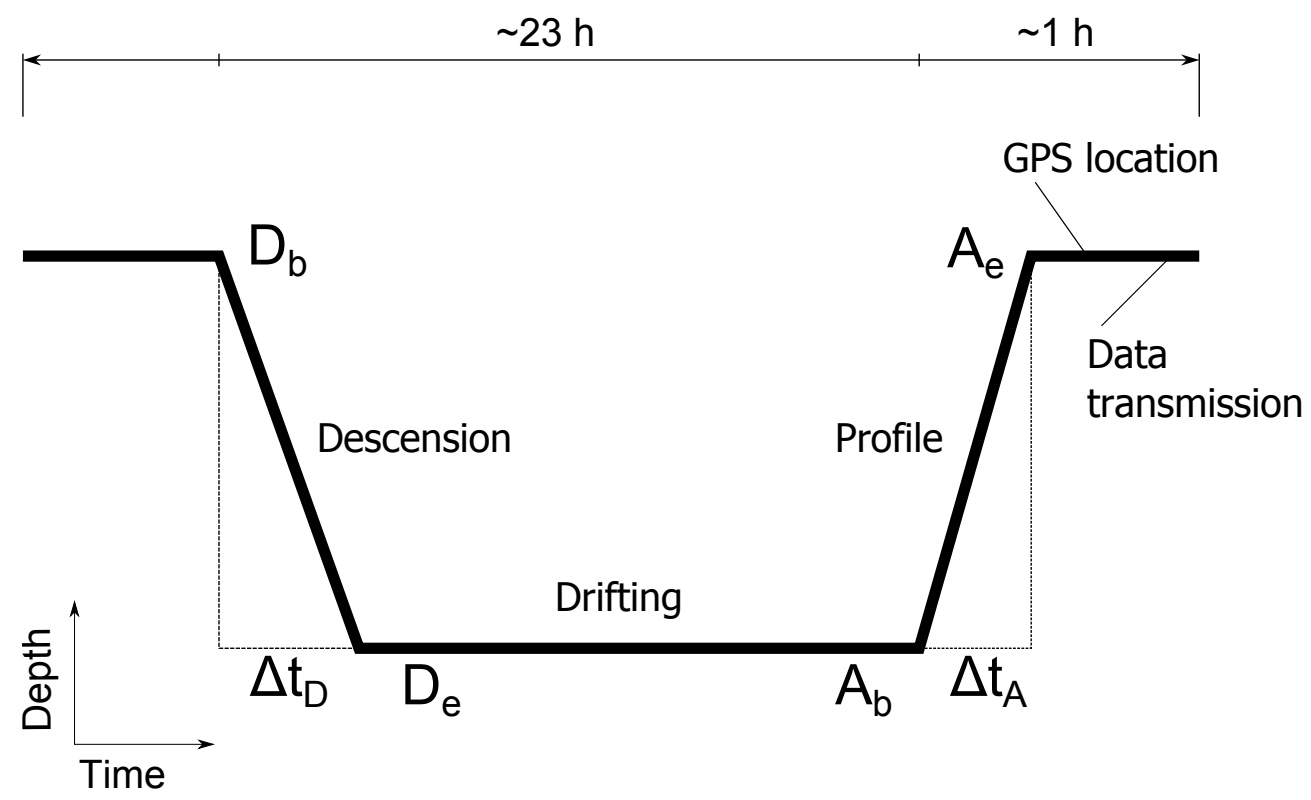

Figure 2.1 Schematic illustration of APEX cycle in the Baltic Sea (from Publication III) The profile starts from the parking depth. $D_{b}$ marks the beginning of the descent to the parking depth and $D_{e}$ marks the beginning of the drifting phase. $A_{b}$ and $A_{e}$ mark the beginning and the end of profile sampling respectively, and $\Delta t_{D}$ and $\Delta t_{A}$ are the descension and ascension times, respectively.

stages: in real time (within 24 hours from recording) and in delayed mode (within 1-2 years) (Barker et al. 2011). For the Baltic Sea measurements, only the real-time quality control is performed. However, the delayed mode quality control is under development.

\subsubsection{Measured variables and units}

For the temperature (T) and salinity (S) measurements in Publications I and II, density and absolute salinity for the Argo and CTD (Conductivity, Temperature, Depth) profiles were calculated using the Python implementation of the Thermodynamic Equation Of Seawater - 2010 (TEOS-10) (IOC et al. 2010). Although the salinity data presented in Publications I and II are in absolute salinity, the values from literature are presented as they were in the original work, which was usually in practical salinity. The difference between absolute salinity and practical salinity is approximately 0.1 in the Baltic Sea, with absolute salinity being higher, and this is taken into account in the comparisons. Temperature shown is the in-situ temperature, except for T-S diagrams, for which potential temperature was 


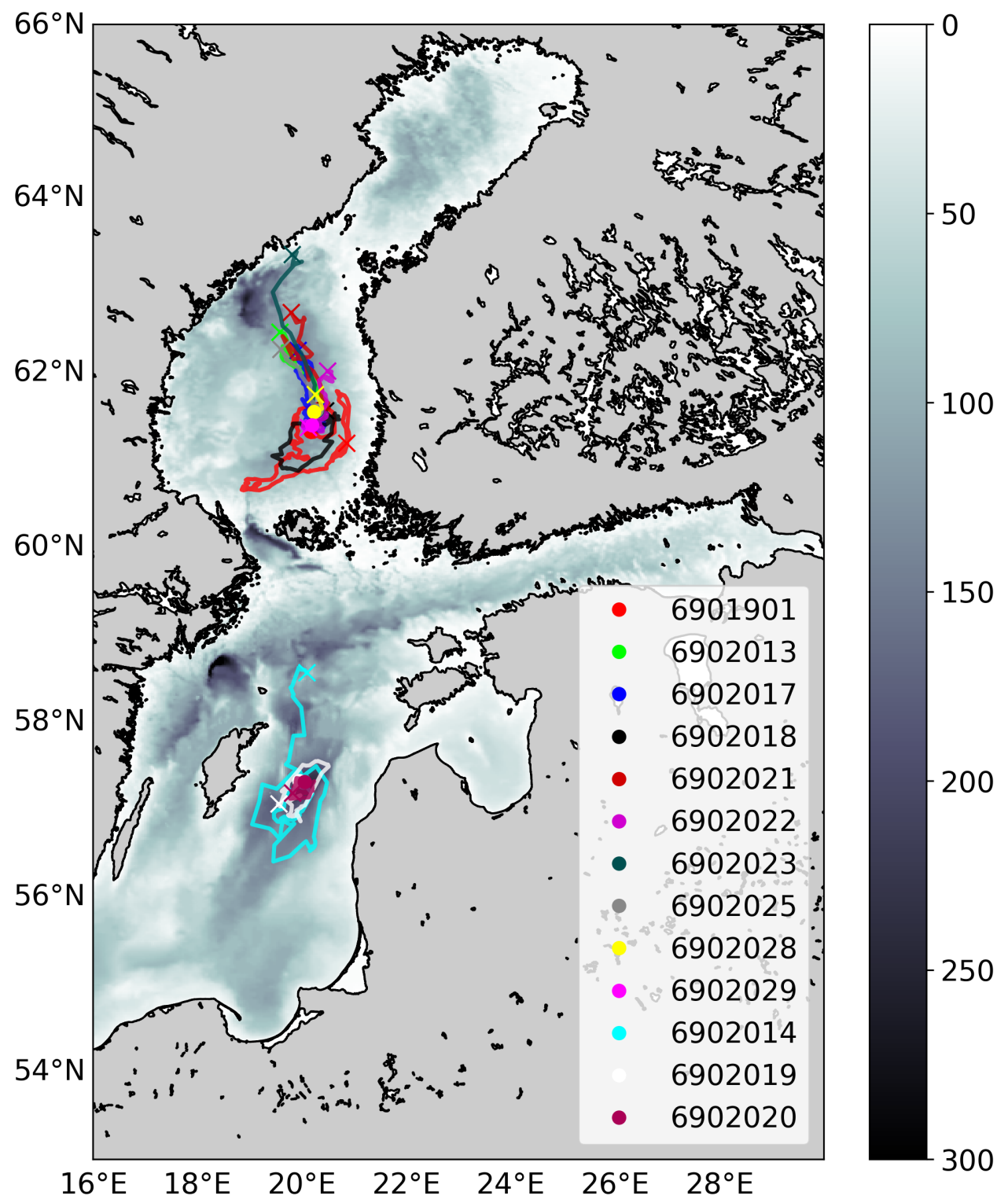

Figure 2.2 APEX measurements in the Baltic Sea (Publications I, II and III). The location of the deployment is marked with a circle and the mission end point with a cross. The details of the missions are presented in Table 2.1. Figure: Simo Siiriä. 


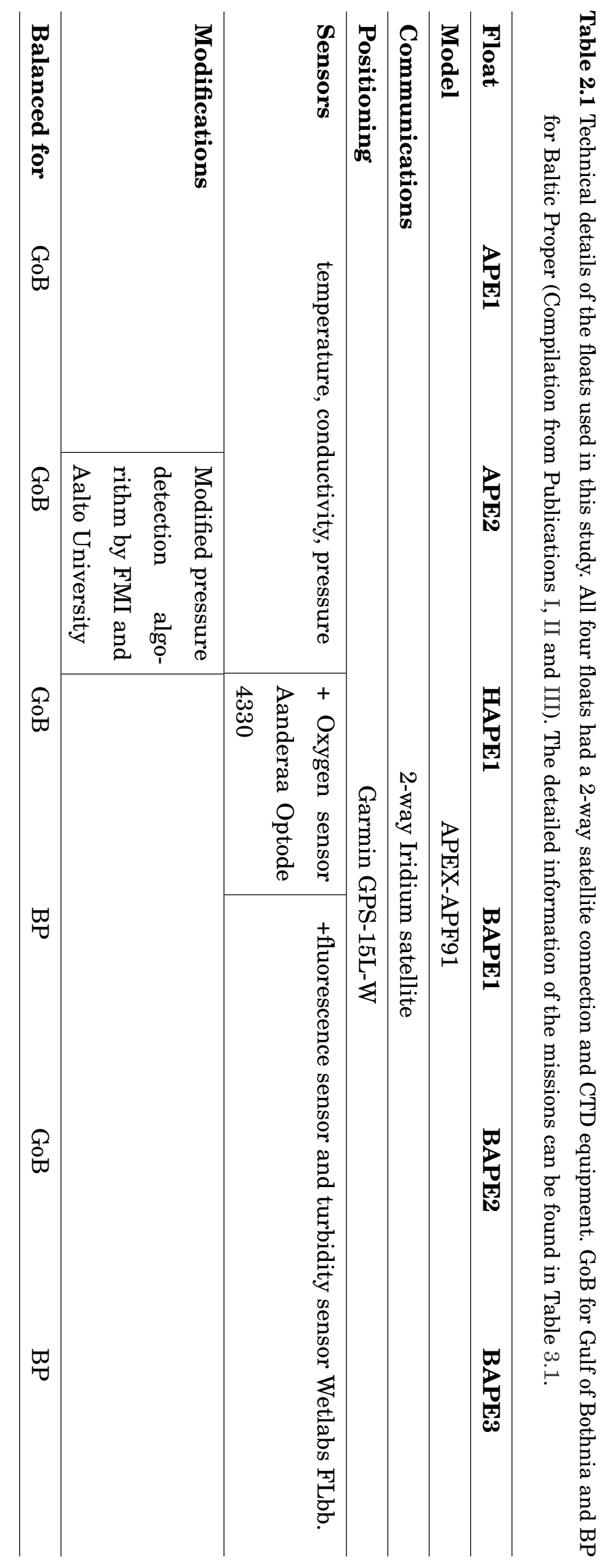


applied. The Argo floats measure the pressure and not directly the depth. In this study the relation between the pressure and depth is considered to be $1 \mathrm{dbar} \sim 1 \mathrm{~m}$.

The location, and thus the movement, of the float is determined by GPS. The GPS error in location is less than 15 metres (95\%). The location is defined once in every measuring cycle, after surfacing. The travelled speed is then calculated from the changed location and the length of the cycle (Publication III).

The currents below 90 dbars are considered to represent the deep currents as this is below the halocline and, according to the results in Publication II, the seasonal variation can reach the depth of almost 100 dbars.

\section{Description of the measurements}

In general, the Argo floats sampled the water column from diving depth to near the surface every 2 dbars until the CTD shut down 4 dbars before the surface due to technical reasons. The exceptions are the profiles that were less than 50 dbars deep, for which, due to a software bug, the sampling interval was 5 dbars. The deepest measured pressure used in this study was 130 dbars.

The average distance from the bottom was estimated from the topography: for the first two missions, A and B (Table 3.1), it was 30 metres and for the rest it was 10 metres. All floats in the Bothnian Sea were deployed within an area of $615 \mathrm{~km}^{2}$, with a distance of $28 \mathrm{~km}$ between each other at most.

The median time between the cycles in the time period of 2012-2016 was 24 hours within the range of two hours to seven days. The longest measurement cycles occurred when the ice avoidance was tested. The shortest possible measurement cycle in the depth range of 100-150 metres is probably from two to three hours.

\subsubsection{The persistency of the currents}

The persistency is a value which indicates the permanence of the currents. In Publication III the deep currents are studied and their persistency is estimated. 
The studied area in the Bothnian Deep (Figure 3.1) was divided to a $3^{\prime} \times 6^{\prime}$ (latitude $\times$ longitude) grid and current observations were averaged for each grid box.

The persistency $(R)$ of the current was calculated by dividing the mean vector speed by the average scalar speed as presented by Palmén (1930):

$$
R=\frac{\sqrt{\bar{u}^{2}+\bar{v}^{2}}}{\frac{1}{N} \sum \sqrt{u_{n}^{2}+v_{n}^{2}}},
$$

where $\bar{u}$ and $\bar{v}$ are the average eastward and northward components of velocity, respectively, $u_{n}$ and $v_{n}$ are the respective components of the velocity in a single cycle, and $N$ is the number of cycles.

\subsubsection{The monthly mean values of temperature and salinity}

In Publication II the monthly mean values of the temperature and salinity were analysed. The amount of Argo and CTD profiles greatly vary between seasons and the same month of different years. The monthly mean values were calculated by first averaging over each month with data and then taking the mean over the years for each month. The amount of measurements is very low below the pressure of 100 dbars, therefore monthly means were considered valid up to a 100 dbars. Winter means were calculated for 2014-2017 due to the lack of winter profiles before 2014 while other seasons also included the years 2012 and 2013.

Halocline and thermocline depths were calculated as the depth of maximum gradient of salinity and temperature. The seasonal halocline was excluded from the analysis by only using measurements under the thermocline when it existed.

\subsection{The forecasting system}

\subsubsection{The BALECO model}

In this study, the FMI's operational three-dimensional, coupled hydrodynamic and biogeochemical model, BALECO, was used (operational until 2011). In Publication IV the focus is on SST and in Publication V on HABs. The model consists of two components: the general circulation model, MIT- 
gcm (Marshall et al. 1997a,b) and an ecological module (Publication V, Appendix A). The computational model was discretised on a spherical polar grid. The grid size was $0.2^{\circ} \times 0.1^{\circ}$ (latitude $\times$ longitude), which is approximately $6 \times 6$ nautical miles $(11.1 \times 11.1 \mathrm{~km})$. The model domain was 120 $\times 108 \times 21$ grid cells (latitude $\times$ longitude $\times$ vertical). The model domain's most south-western corner was located at $53.85^{\circ} \mathrm{N}, 8.7^{\circ} \mathrm{E}$. The biological activity is greatest in the euphotic zone so the vertical resolution of the top most layer was $3 \mathrm{~m}$, reduced to $2 \mathrm{~m}$ in the cells near the coast (Kiiltomäki 2008). The bottom topography was taken from the work of Seifert and Kayser (1995). The spatial discretisation was made with minimum filter at $6 \mathrm{NM}$ intervals. The biogeochemical model appeared to have a tendency to have a slight warm bias of around $0.5^{\circ} \mathrm{C}$ (Kiiltomäki 2008).

The ecological model used in Publication V is based on ecosystem dynamics formalised by Aksnes et al. (1995) and Tyrrell (1999). The model has three phytoplankton groups: diatoms, flagellates and cyanobacteria. These groups have constant mortality rates and they use phosphate, silicate and dissolved inorganic nitrogen (DIN). Diatoms are potentially limited by the availability of silicate. Cyanobacteria can fix molecular nitrogen and therefore they are not limited by the availability of DIN. The flagellates group represents autotrophic flagellates. Altogether, the ecosystem model describes the essence of new production in the presence of three functional groups. Their growth rates depend on nutrient concentrations, irradiation and temperature (Stipa et al. 2003).

The ensemble forecast initial state was taken from the FMI's deterministic Baltic Sea forecast for the forecast's start date of the run. The initial conditions for the deterministic forecast, both physical and chemical conditions, were obtained from the winter monitoring data of the HELCOM COMBINE programme for the winter 2007-2008. The observations were interpolated in three dimensions with a robust nearest-neighbour interpolation and then supplemented by climatological values for the North Sea from the World Ocean Atlas (Boyer et al. 2006).

\subsubsection{Generation of the ensemble forecasts}

In Publications IV and V the ensemble forecasts were created from an unperturbed initial ocean state by running the model several times with perturbed sets of weather forcings. The unperturbed ocean state was taken from the routinely produced deterministic short-term Baltic Sea model 
forecast. The weather ensembles were from the monthly forecasting system of ECMWF (European Centre for Medium-Range Weather Forecasts), which is based on the Integrated Forecasting System atmospheric model (from cycle CY32R3V in 2008 to CY35R3 in 2009). They were created with the singular vector method (Molteni et al. 1996). The weather parameters used as external forcing for the BALECO model were six-hourly winds at $10 \mathrm{~m}$, temperature and dew point temperature at $2 \mathrm{~m}$ and 12-hourly surface solar radiation and surface thermal radiation. The wind stress was calculated by the model of ECMWF for $10 \mathrm{~m}$ wind forcings.

In some cases with stormy winds, the wind stress grew large in certain areas of the model domain, destabilising the system. As model stability and forecast availability are paramount for an operational forecasting system, this is compensated for by restricting the stress value growth over a threshold value. These weather ensembles consist of 50 perturbed ensemble members and an additional deterministic unperturbed control run. Forecasts were made at one-week intervals.

\section{Upwelling forecasts}

Haapala (1994) used the wind impulse per unit area to quantify the effect of wind. He found that the wind impulse needed to cause an upwelling during thermal stratification was $4000-5000 \mathrm{~kg} \mathrm{~m}^{-1} \mathrm{~s}^{-1}$ and in a thermally homogenous situation it was $10500-14000 \mathrm{~kg} \mathrm{~m}^{-1} \mathrm{~s}^{-1}$. Impulses calculated from the input fields used in this work are in agreement with these findings. The upwelling forecast was showcased in the Publication IV, where an upwelling phenomena was detected from satellite images and from in-situ measurements, when possible.

During an upwelling event, the typical change in surface temperature is from 1 to $5^{\circ} \mathrm{C} /$ day (Lehmann and Myrberg 2008). Accordingly, $1^{\circ} \mathrm{C} /$ day was used as a threshold lower limit for an upwelling event. In forecasting the upwelling events, the interest is mainly on the timing in order to be able to, for example, estimate the possibility of fogginess in a coastal area. The monthly scale prediction could then be refined by shorter-term forecasts. In Publication IV the forecast was evaluated as being successful if the cooling period started during the upwelling period in the tide gauge and satellite observations. 


\section{$H A B$ forecasts}

The model calculates the amount of cyanobacteria as a molar amount of nitrogen $(\mathrm{N})$. Therefore, to be able to calculate the chlorophyll-a concentration in $\mathrm{mg} \mathrm{m}^{-3}$, the results were compared with observations and a threshold value for the forecasts was set. At the moment there is no concentration limit or standard for visible HABs. In Publication V the limit was set to be $2 \mathrm{mg} \mathrm{m}^{-3}$ based on the relevant literature (Kutser 2006, Mazur-Marzec 2006) and uncertainties in nitrogen-chlorophyll conversion. To calculate the amount of cyanobacteria in chlorophyll-a, the special C:N and C:Chla ratios were used.

\subsubsection{System verification methods}

The representability of the SST ensemble distributions, as well as the quality of the ensemble forecasts were verified by the three methods: the rank histogram, the continuous rank probability score (CRPS) and residual-quartile-quartile ( $\mathrm{R}-\mathrm{Q}-\mathrm{Q})$ method. The quality of the upwelling forecasts are then verified by probability of detection (POD) value and false alarm rate (FAR) value.

\section{Rank histogram}

In Publication IV, a rank histogram was used to compare the ensemble SST distribution with observation distribution. The observation data was from Northern Baltic Proper wave buoy (Section 2.3.1). A rank histogram (Anderson 1996, Hamill and Colucci 1997, Talagrand 1999) is probably the tool most used for analysing ensemble forecasts (Jolliffe and Stephenson 2003). The histogram is useful in determining the reliability of an ensemble forecast and as a diagnostic tool for analysing the mean and spread. The method has been proven applicable for forecast verification. However, it should be used carefully with other verification methods to ensure the forecast quality. In general, a flat histogram means that the spread of the ensemble covers the spread of the observations and the distributions are indistinguishable and thus have an ideal rank uniformity (Wilks 2011). The differences from the ideal rank uniformity can be used to analyse the inefficiencies of the ensembles. However, there are caveats which are presented in depth by Hamill (2001). 


\section{CRPS}

In Publication IV, CRPS method was used to evaluate the SST ensemble forecasting system. The observation data for comparison was from a Northern Baltic Proper wave buoy (see Section 2.3.1). CRPS can be interpreted as an integral over all possible Brier scores (Jolliffe and Stephenson 2003). For deterministic forecast CRPS is equal to the mean absolute error (MAE) and thus allows clear interpretation (Hersbach 2000, Wilks 2011).

CRPS is defined as follows, where $x$ is the parameter of interest (e.g. SST) and $x_{a}$ is the value that actually occurred:

$$
C R P S=\int_{-\infty}^{\infty}\left(F(x)-F_{a}(x)\right)^{2} d x
$$

where

$$
F_{a}(x)= \begin{cases}0, & \text { if } x<\text { observed value } \\ 1, & \text { if } x \geq \text { observed value }\end{cases}
$$

and $F(x)$ is the forecasted probability that $x_{a}$ will be smaller than $x$.

\section{The $R-Q-Q$ method}

The R-Q-Q method is a graphical tool for analysing if two datasets have a common distribution. This method was used in Publication IV to compare SST ensemble distribution with wave buoy observations (see Subsection 2.3.1). The R-Q-Q method is similar to Quartile-Quartile plot, but instead of plotting the forecast quartiles versus observation quartiles, it plots the difference or "residual" of the two quartiles on the $y$-axis. The R-Q-Q plot graphically compares data with the reference distribution and is sensitive to differences in mean and variance between the forecast and observations (Marzban et al. 2011, Wilks 2011).

\section{$P O D$ and FAR}

In Publication IV the performance of the upwelling forecasts is estimated with numerical values called POD and FAR (Donaldson et al. 1975) using contingency table (Table 2.2).

The probability of the event depends on the selected threshold value for the studied phenomenon. The observation is "true" when the threshold limit is exceeded, and the same is valid for the forecast. 
Table 2.2 Contingency table for defining POD and FAR

\begin{tabular}{|c|c|c|c|}
\hline & \multicolumn{2}{|c|}{ Observation } \\
\hline & & True & False \\
\hline \multirow{2}{*}{ 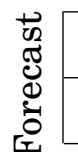 } & True & $\mathrm{a}$ & b \\
\hline & False & c & $\mathrm{d}$ \\
\hline
\end{tabular}

The POD and FAR values can then be defined as follows:

$$
P O D=\frac{a}{a+c}
$$

and

$$
F A R=\frac{b}{a+b}
$$

respectively.

In Publication IV the upwelling forecasts are evaluated with this method by setting the threshold value of SST change to be at minimum $1^{\circ} \mathrm{C} /$ day. The observations used for the evaluation are from satellite tide gauges (see Section 2.3.1).

\subsubsection{Illustration of the probabilities}

Ensemble forecasts contain a large amount of information. Compared to deterministic forecasts, the interpretation and communication of the uncertainties are more challenging. In Publications IV and V these issues were approached with different types of figures, which show, for example, the spread of the ensemble members and the probability of different events.

In Publication IV the results were illustrated with plumes (Figure 7) and with quartile plots for a single point (Figure 5). In addition to Ensemble Prediction System (EPS) plumes of temperature, the upwelling phenomenon was studied with violin plots of the time derivatives of the variable. Violin plots combine a box plot and kernel density (Hintze and Nelson 1998). White dots inside the plots indicate the median value. In general, violin plots give more information than box plots, especially when working with skewed distributions. Since forward differentiation was used to calculate the temperature derivative the violin plots are one day shorter 
than the EPS plumes. This method allows examination of the temperature change distribution more closely and identification of the possible upwelling events.

In Publication $\mathrm{V}$ the $\mathrm{HAB}$ probability maps were presented and compared with Alg@line data and a map based on visual observations (see Section 2.3.1).

\subsection{Validation data}

\subsubsection{Observations}

\section{CTD data}

CTD data was used in this study (in Publications I and II) to compare the Argo results in the Bothnian Sea with existing and established hydrographical results. The CTD data is typically measured from the research vessel during monitoring cruises (COMBINE). Finland is responsible for monitoring the hydrography of the Bothnian Sea together with Sweden. The implementation of the CTD measurements is described more closely by HELCOM (2017).

CTD data was measured on the Finnish research vessel $R$ / V Aranda in the Bothnian Sea during 1998-2017. A Seabird CTD has been on board Aranda since 1997, and thus this 20-year measuring period is considered to be consistent in terms of measurement set up and errors. The average number of CTD profiles per month was three for 1998-2017 and two for 2012-2017, although it greatly varied, depending on monitoring and research campaign timing, with about four months in a year having no measurements.

\section{Tide gauges}

Tide gauges measure the water level as well as water temperature around the Finnish coast. The data used in Publication IV was 10-minute data which was averaged over 24 hours. The tide gauge data was used to analyse the water movements in the Bothnian Sea basin (see Publication III) and the sudden decrease of temperature during the upwelling events (see Publication IV). Further details of the tide gauge data and methods 
were given by Johansson et al. (2001).

SST from a wave buoy

For general analysis of the performance of the ensemble forecast system (see Publication IV), the wave buoy measurements of SST from the Northern Baltic Proper (59 $\left.{ }^{\circ} 15^{\prime} \mathrm{N} 21^{\circ} 00^{\prime} \mathrm{E}\right)$ were used. Further information on the data from the buoy can be found in the work of Kahma et al. (2003). The buoy measurements were taken every half an hour and averaged over 24 hours.

\section{Satellite data}

Satellite SST observations were used to identify the upwelling events in Publication IV. This dataset was based on data from the National Oceanic and Atmospheric Administration (NOAA) AVHRR satellite. Each image was processed using a split window method and cloud detection algorithm at SYKE (Finnish Environment Institute) (SYKE 2015).

\section{Alg@line data}

The biomass data from the Alg@line project (Ruokanen et al. 2003) was used to compare forecasted HABs with observations in Publication V. The data was collected by ferries operated by shipping companies. The ferries have a flow-through system called Ferrybox, which is equipped with GPS, thermosalinograph, chlorophyll, phycocyanin and coloured dissolved organic matter (CDOM) fluorometers, a turbidity meter and a refrigerated sampling unit.

\section{Wind observations}

Wind observations from weather stations around the Bothnian Sea and the Baltic Sea Proper were used in Publications I, II and III to analyse the effects of the wind on the sea. The stations are administered by the Danish Meteorological Institute (DMI), the Swedish Meteorological and Hydrological Institute (SMHI) and FMI and the average wind is calculated by the governing institute. 


\subsubsection{D hydrodynamic model data}

For comparing estimated velocities from floats in the Bothnian Sea (see Publication III) and analysing surface drift errors, the two nautical mile (NM) set-up of the NEMO 3D ocean model (V3.6), covering the Baltic Sea and North Sea area, was used. The model wasrun from June to December 2014 (Hordoir et al. 2013, 2015, 2018).

The vertical resolution of the NEMO set-up was $3 \mathrm{~m}$ on the surface, and layer thickness increased with depth. There were altogether 56 layers in this configuration. The time step of the model was 15 minutes and the results were saved as one day averages. The bathymetry of the set-up was updated to the latest version of the NEMO Nordic bathymetry . The more detailed description of the bathymetry in this model setup can be found in Hordoir et al. (2018). River run-offs and precipitation fields were climatological. The atmospheric forcing for the model was achieved from the FMI numerical weather prediction system HIRLAM (HIRLAM-B 2015). Forcing was read into NEMO with the CORE bulk formulae (Large and Yeager 2004). 


\section{Results}

\subsection{Hydrographical measurements}

\subsubsection{A general description of the hydrography in the Bothnian Sea}

In Publication II the Argo measurements were used for the years 20122017 in the Bothnian Sea (Table 3.1 and Figure 3.1). During this period the ice avoidance algorithm was tested but not used in real ice conditions.

The near surface ( $4 \mathrm{dbars}$ ) temperatures varied from $0.1^{\circ} \mathrm{C}$ to $22.7^{\circ} \mathrm{C}$ and salinities from $4.18 \frac{g}{k g}$ to $5.74 \frac{g}{k g}$. The deep measurement depth studied was 100 metres, since it is the deepest HELCOM standard depth and it is always below the estimated halocline depth. The monthly mean temperature in this depth varied from 3.6 to $4.5^{\circ} \mathrm{C}$ and the monthly mean salinity varied from 6.24 to $6.47 \frac{g}{k g}$ (see Publication II, Figure 3).

The mean temperatures measured with Argo floats closely followed the mean temperatures presented in earlier studies (Lentz 1971). There were some differences, for instance, the summer mean temperature was a couple of degrees warmer and bottom temperature variation was smaller.

On average, the salinity was also close to values found in the related literature both near the surface and below the halocline. However, the variation appeared to be smaller than in the literature and the measured values in general were at the lower end of the range found in the literature. 


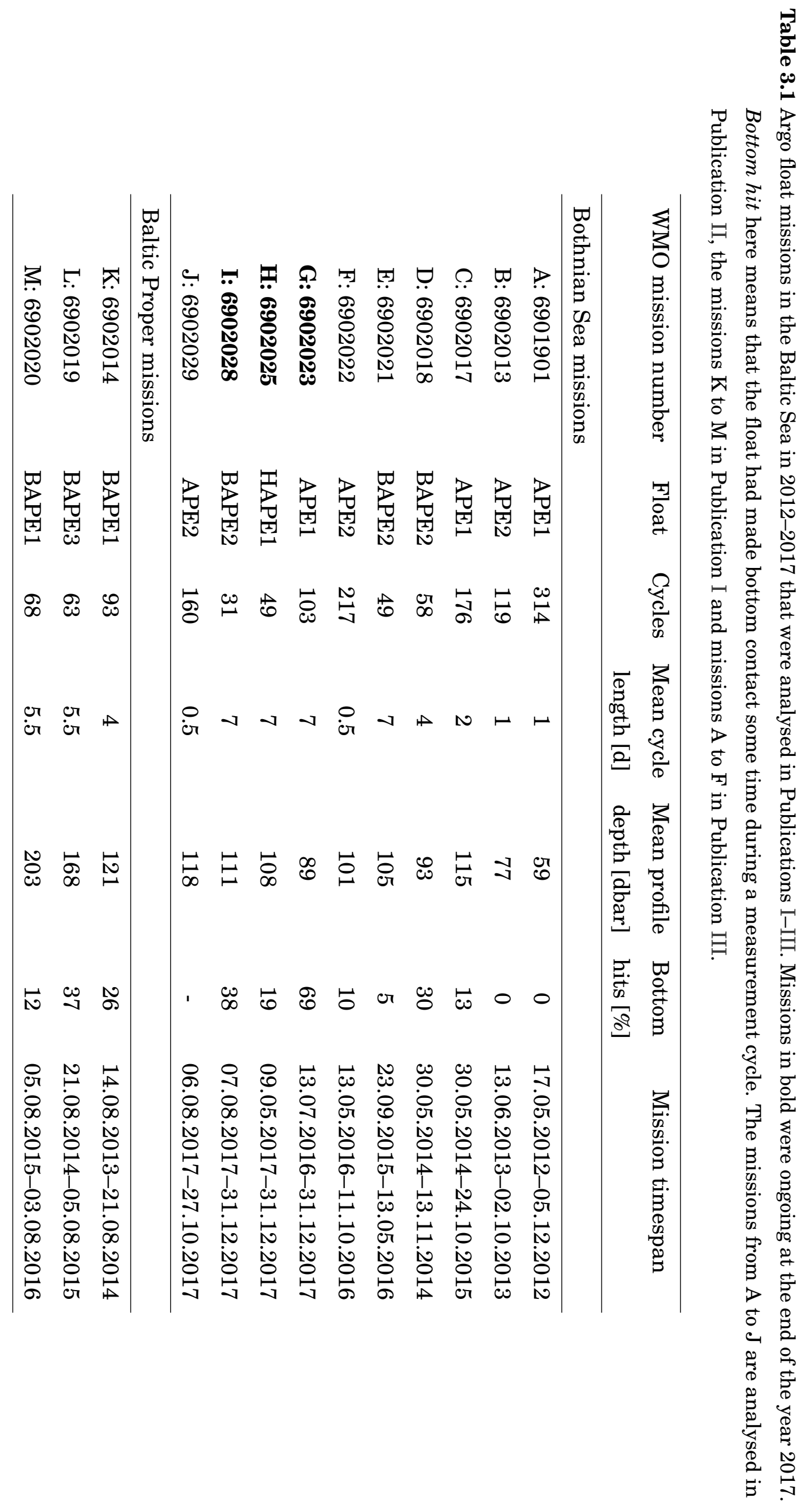




\subsubsection{Small-scale events}

In Publications I and II an Argo floats' ability to measure three small-scale hydrographical events was showcased. The timescale in all three events was in order of days and the spatial scale of an order of kilometers. The first two cases were rapid wind-mixing events on the surface layer that took place in the Eastern Gotland Basin and the Bothnian Sea. The third event was the detection of warm water lenses in the Bothnian Sea, which were potentially caused by a wind-induced downwelling event.

\section{Warm water lenses}

Two lenses of relatively warm water were measured under the halocline at a pressure between 60 and 100 dbars after 15 October 2017 (see Publication II, Figure 8). The temperature in these lenses was $1.3^{\circ} \mathrm{C}$ warmer than the surrounding water mass. The event could be seen in the measurements for ten days. During the event the float drifted approximately nine kilometres. This event was probably caused by hard NW-NE winds between 5-10 October, which had triggered a downwelling event on the western side of the Bothnian Sea.

Two missions, Missions I and J (Table 3.1), were measuring during this period, the latter having a high measurement frequency ranging from two hours to 24 hours and the former having a low measurement frequency set to seven days. The aforementioned lenses could be detected by Mission $\mathrm{J}$ with the higher measurement frequency, but were either missed completely or their durations and magnitudes were not fully captured by Mission I with a measurement cycle of a week.

\section{Wind-induced mixing in the surface layer}

In the Eastern Gotland Basin the formation and the decay of the thermocline were detected from the temperature and salinity measurements made in Mission K (Table 3.1). Publication I presents an event that occurred in the autumn of 2013 when the hurricane-class storm "Christian" crossed the Baltic Sea Proper in October 28. The maximum 10-minute average wind speed measured during the storm was $39.5 \mathrm{~m} / \mathrm{s}$ in Denmark. From 28 to 29 October the wind speed varied from 17.4 to $22.1 \mathrm{~m} / \mathrm{s}$ at the Östergarnsholm weather station, on the Gotland Island. This weather station was the closest station to the Argo measurement area. Also, the maximum significant wave height measured by the Northern Baltic Proper 
wave buoy was 5.2 metres. The float's measurement cycle lasted five days at that point. Figures 10 and 11 in Publication I show how the strong thermocline eroded during the storm between the measurements on the 24 and 29 October.

Mission J (Table 3.1), at the end of October 2017 in the Bothnian Sea was set to measure a profile every two hours to capture a storm event (see Publication II, Section 3.2). During the storm the thermocline deepened 10 dbars, changing from 30 dbars to 40 dbars, and the uppermost surface layer Argo measurement cooled by $0.9^{\circ} \mathrm{C}$ during the 24-hour period. The storm event was seen from the weather forecasts well in advance and the profiling mode was changed before the storm reached the studied area.

\subsubsection{Estimation of currents}

In Publication III the currents in the Bothnian Sea with Argo floats were analysed. There were altogether six Argo float missions during the years 2012-2016, which used three different floats (see Table 3.1). Five missions were launched at the beginning of summer (between mid-May and midJune), and one mission was launched in September. The deployment of the floats took place near the same location in the middle of the Bothnian Sea deep (Figure 3.1). This was to avoid bottom contact and collisions with other vessels. During the winter time, the ice avoidance was also tested.

In Publication III the currents in the Bothnian Sea, measured with Argo floats, were analysed and methods for surface drift estimation were presented with both drifting measurements and hydrodynamic model estimates.

\section{A general description of the currents in the Bothnian Sea}

The mean distance the float moved during a one measurement cycle was two to three kilometres. The average current speed was $2 \mathrm{~cm} / \mathrm{s}$, which is considered to be an average residual speed in the deep waters (Alenius 1993). High speeds over $10 \mathrm{~cm} / \mathrm{s}$ were very rare, and only estimated to occur in $3 \%$ of the cases, in fairly shallow depths. The majority of the floats' trajectories followed the expected resultant current towards the north (Publication III, Figure 7). 
The speed estimates were compared with the current velocities calculated by the NEMO model (see Section 2.3.2). At each profile point the corresponding grid point from the model domain was chosen. The model run took place from June to December 2014 (altogether for seven months). The results from the float and the model were not directly comparable because the time scale of the events suitable for investigation by the NEMO model was limited by the structure of the model configuration and available inputs for the model. To be able to assess the magnitude of the velocities the velocity distributions from the model and observations were compared (see Publication III, Figure 4).

In the modelled period from June to December 2014 there were three occasions when there were strong winds and the float's drift speed exceeded $7 \mathrm{~cm} / \mathrm{s}$ during the measurement cycle (see Publication III, Section 3.1). On the two first occasions presented in Publication III, the current speeds modelled by NEMO and estimated from Argo trajectories represented the highest $5 \%$ of the current speeds in that time period. Because of this, both Argo and model current speed estimates were considered to be exceptionally high during these events. On the last occasion the wind direction was southward and there were no clear signals of higher current speeds in the model results, even though the observations suggested strong currents.

The possible sources of differences between the model results and observation could be, for example, related to weather forcing. It was possible that the routes of the low pressure systems were not described exactly by the weather models. It was also possible that the float had drifted on the surface longer than expected. The bathymetry was poorly known in the area and that could cause differences between the model and observation.

\section{Currents in the Bothnian Sea Deep}

In Publication III the currents in the Bothnian Sea Deep were analysed (see Figure 3.1). On average, the floats drifted in the deep in 106 dbar pressure, which is 13 dbars more than the average of all Bothnian Sea measurements. The maximum pressure was 126 dbars. The speed estimated from float movement was on average $2 \mathrm{~cm} / \mathrm{s}$, which is in accordance with the whole of the Bothnian Sea results (Alenius 1993), and the temporary maximum was $13 \mathrm{~cm} / \mathrm{s}$ (see Figure $3.2 \mathrm{~b}$ ). The main directions of the currents ran along the north-south axis, with the major part of observations showing a northward 


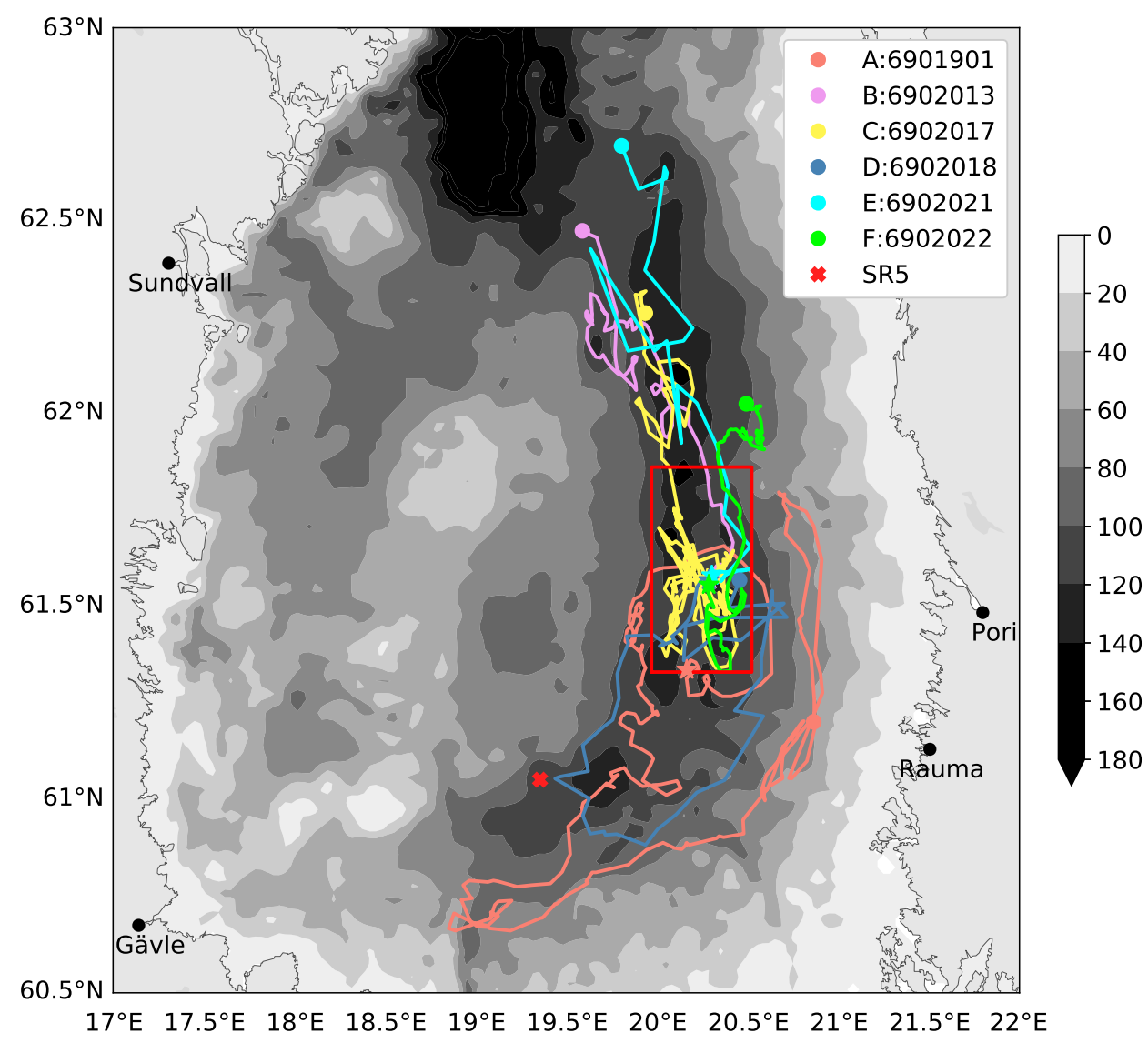

Figure 3.1 Argo missions in Bothnian Sea deep area. There were altogether 257 measurement cycles analysed for this study. The bathymetry is shown in greyscale and the studied area is marked with red box. The routes of the missions are marked with other colours.

movement. The $\mathrm{N}-\mathrm{W}$ to $\mathrm{N}$ sector covered $37 \%$ of all the observed directions, while the sector from S-S-W to S-S-E covered around $22 \%$ of all directions (Figure 3.2a).

The Bothnian Sea deep was gridded and the persistence for the different grid boxes was analysed as described in Section 2.1.2. The persistence varied from $17 \%$ to $96 \%$ in the grid boxes that had over eight measurements. It was common that the measurements in the same grid box were more or less consecutive, therefore synoptic-scale weather phenomena could explain the high persistency value. 


\subsection{Monthly ensemble forecasts}

\subsubsection{Forecasting upwellings}

In this study the interest in upwelling forecasts was in regard to timing. If the timing of the event is known, it is possible, for example, to forecast fogginess in a coastal area. The monthly scale forecast can then be refined to shorter-term forecasts in order to have a closer look at the event. In Publication IV SST forecasts were produced for the Baltic Sea. These forecasts were then analysed and a threshold value for the upwelling event was defined (see Section 2.2.2). The forecasts were then verified by using the methods described in Section 2.2.3. The forecast was evaluated to be successfull if the cooling period in the forecast started during the upwelling event in observations (see Section 2.3.1).

Altogether there were 13 measured upwelling events, which could be detected on one or more of the eight tide gauges during the study periods between 2008 and 2009. The forecasts were divided into three categories: forecasts of up to seven days, forecasts ranging from seven to 14 days and forecasts for over 14 days. The shortest forecast period predicted 11 upwelling events, the second six and the longest two.

The POD value (see Equation 2.4) was $84.6 \%$ for the shortest forecast, $46.2 \%$ for the two-week forecast and $15.4 \%$ for the more-than-two-week forecast. The FAR value (see Equation 2.5) from all forecasted events was $15.4 \%$ for the up-to-a-week forecast, $68.4 \%$ for the two-week forecast and $84.6 \%$ for the longest forecast. For the shortest forecast period, the ratio of detected upwelling events was high and there were very few false alarms. As the forecast period extended POD decreased and FAR increased. According to these results the longer-than-two-week upwelling forecasts had only little skill.

\subsubsection{Forecasting harmful algal blooms}

In Publication V one case study was made to show whether it is possible to produce quantitative $\mathrm{HAB}$ forecasts with the aforementioned ensemble prediction system. Figure 3.3 shows an example of a monthly ensemble forecast of the amount of cyanobacteria and SST on the east coast of the Gotland Island. The algae situation was measured 10 days earlier by 
Alg@line, showing a blue-green algal biomass on enroute from Helsinki to Travemünde (see Publication V, Figure 5). The amount of algae biomass was significantly lower on the east coast of Gotland, which implies that there was a possible ongoing upwelling event. The lower cyanobacteria biomass concentrations observed near the coast were captured by a large number of ensemble forecast members (see Figure 3.3b). Also, the forecasted SST results implied an upwelling event in the area (see Figure 3.3a).

The two-week harmful algal probability forecast made on 10 July 2008 (see Publication V, Figure 7) was also compared with blue-green algae visual observations collected by Finnish Institute of Marine Research from 22-24 July 2008 (see Publication V, Figure 6). It could be seen that in many areas in the Gulf of Finland, where a high probability of HABs were forecasted, there were also several observations of HABs. On the other hand, in the Baltic Proper the HABs were observed on the western side of the Gotland island when the forecasted higher probability of the blooms was on the eastern side. Also, there were HAB observations in the Archipelago Sea, but the forecast gave low probabilities of HABs.

\subsubsection{Verification of the forecasting system}

Verification deals with the functionality of the forecasting system to assess, for example, if the system produces forecasts that accurately represent the distribution of real-world events. Usually, the information about the error and its change as a function of the forecast length is wanted. These questions were studied with two methods used widely in meteorological applications (see Section 2.2.3).

A SST rank histogram that combined monthly ensemble forecasts from 2008 and 2009 showed that the temperature observations from the Northern Baltic Proper wave buoy tended to fall in the lower bins than was statistically expected (see Publication IV, Figure 2). The histogram indicated that the system was slightly biased. The rank histogram also showed that the spread of the ensemble did not cover enough of the future possibilities and many observations tended to fall outside of the forecast plume.

CRPS showed that the error between the SST observation and the ensemble grew as the span of the forecast grew (see Publication IV, Figure 3). On 
average, the error between the forecast and the observation tended to grow by around $0.01^{\circ} \mathrm{C}$ per forecast day. The initial error between the model and the observation was $0.66^{\circ} \mathrm{C}$, which is in line with the other verifications made for this model before. The variation in temperature between months was quite large, as was also detected from the in-situ measurements (see Publication IV, Figure 4). In general, it was possible to see the growth rate for error during the monthly forecast from CRPS. Despite this, CRPS is a single quantity from which is difficult to see the detailed behaviour of the forecasting system (Hersbach 2000).

The R-Q-Q plot for the SST data (see Publication IV, Figure 5) showed quartile distribution to be somewhat S-shaped, which indicated similar issues to those of the rank histogram: the spread of the ensemble was probably too narrow, and minimum and maximum values were not well produced by the system. The positive slope suggested that the SST variations within the ensembles were larger than within the observations. 


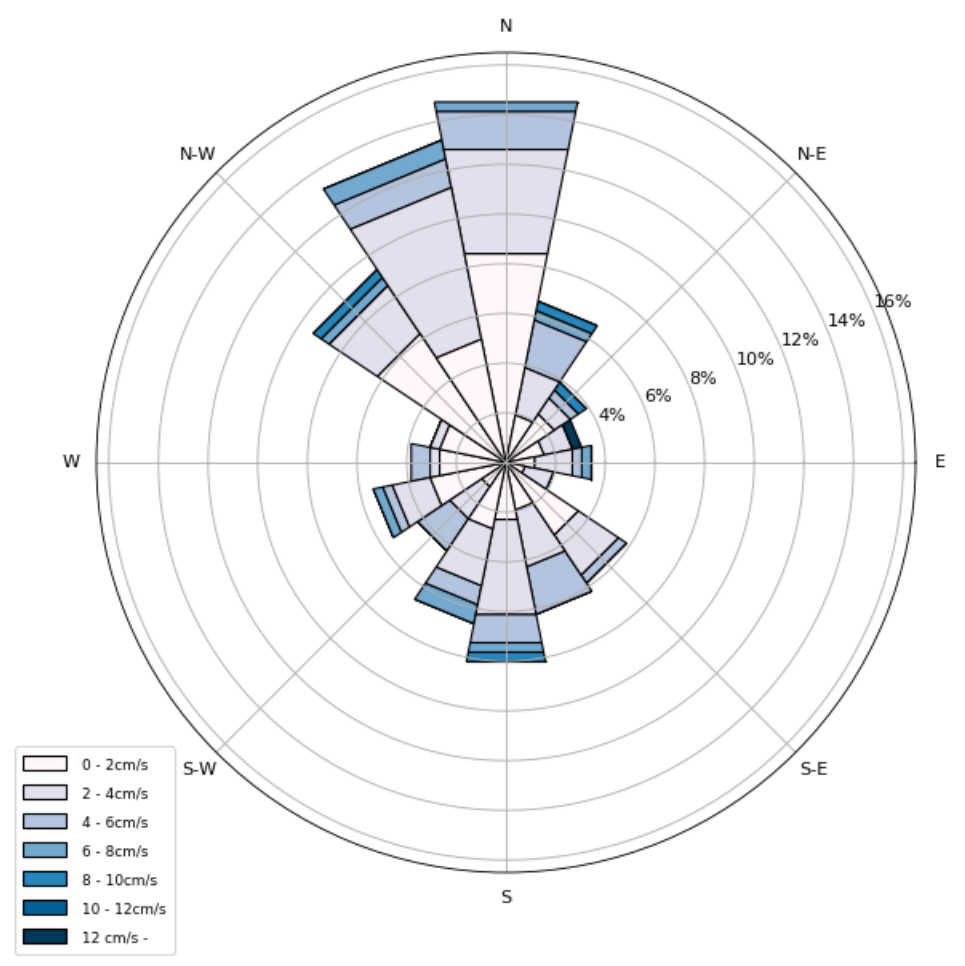

(a)

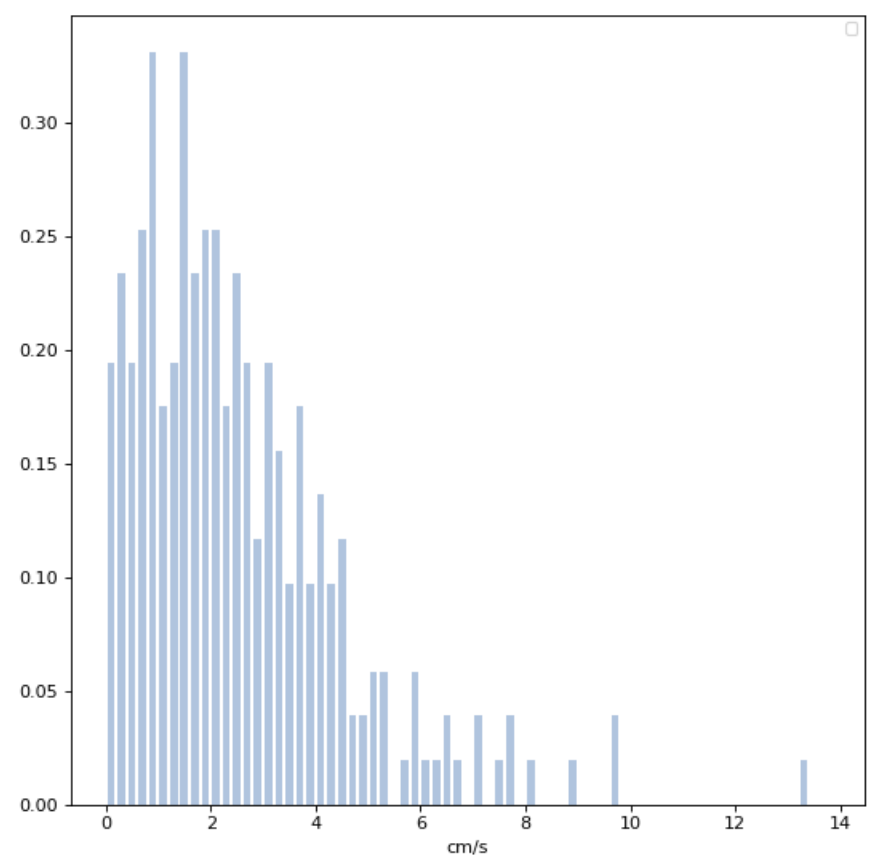

(b)

Figure 3.2 The current rose (a) and probability density histogram (b) showing the directions and distributions of the current speed in the Gulf of Bothnia Deep for Apex Missions A-F (Table 2.1). The figures are drawn from the data in Publication III. 


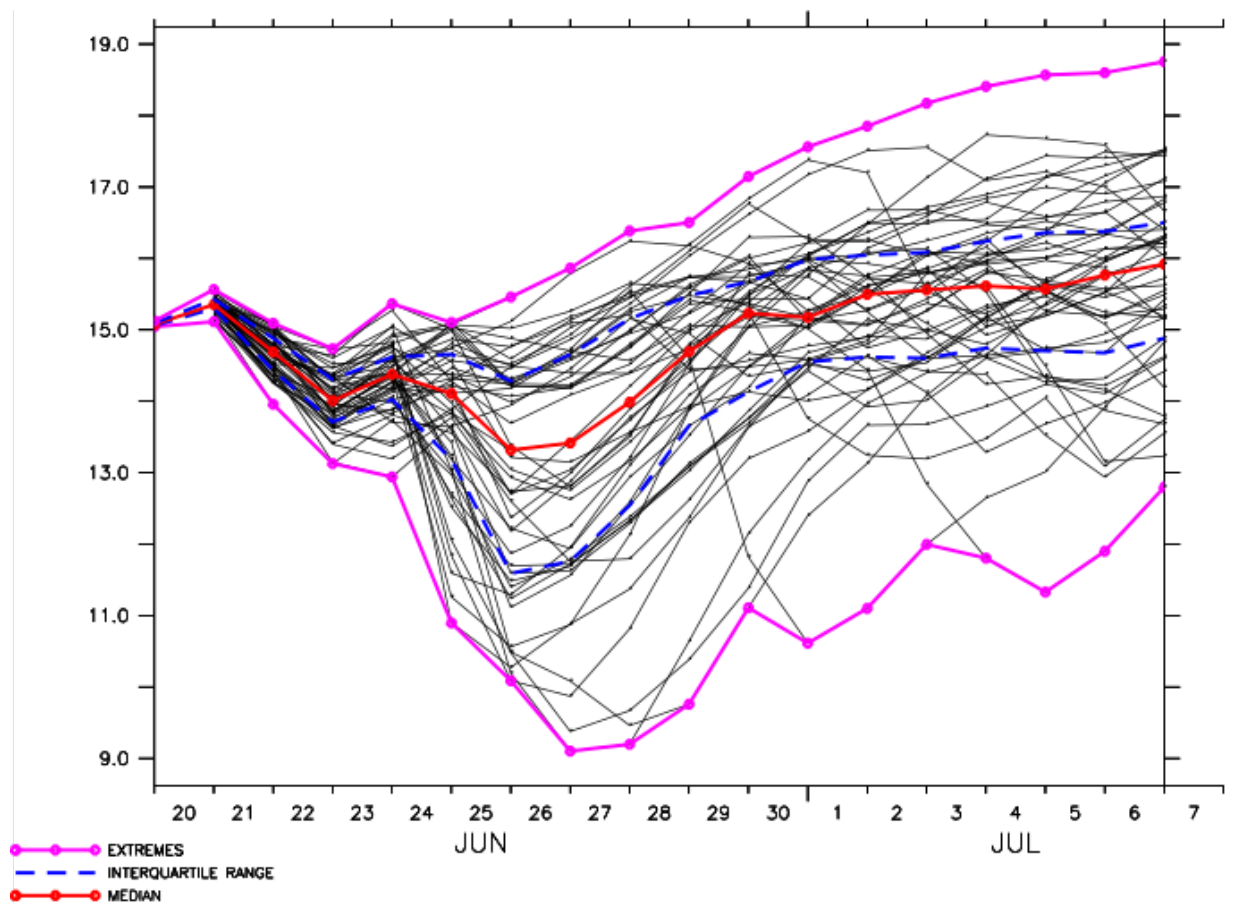

(a) Sea surface temperature $\left({ }^{\circ} \mathrm{C}\right)$

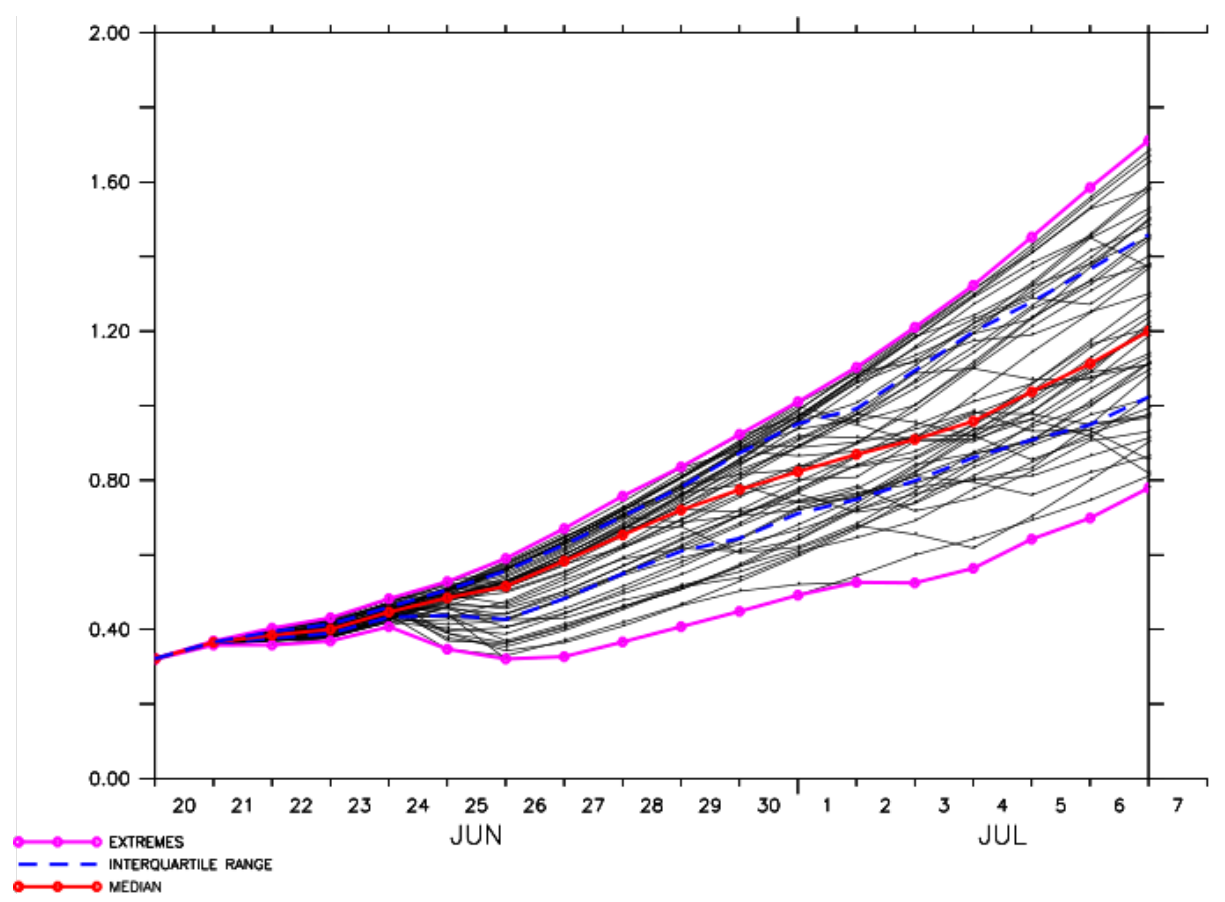

(b) Amount of cyanobacteria $\left(\mathrm{mg} \mathrm{m}^{-} 3\right)$

Figure 3.3 An example of the monthly forecast predicting SST (a) and the amount of cyanobacteria (b). The forecast is made for the east coast of Gotland island $\left(18.10^{\circ} \mathrm{E} 57.25^{\circ} \mathrm{N}\right)$ beginning from 20 June 2008 and ending 7 July. In the SST forecast upwelling event can be seen on 24 June. Figures (a) and (b) are from Publication V 


\section{Discussion}

\subsection{The developments of the operational system}

In this work methods were developed for extending the possibilities of the operational systems of the northern Baltic Sea. These improvements are focused on the new methods for observing the Baltic Sea with autonomous Argo floats, as well as on the new monthly ensemble forecasting methods, described in the previous sections. The observational and computational methods provide a more complete understanding of the state of the sea in the present moment and also in the short- and long-term future. The connections between observations and models in the operational oceanographic system are shown in Figure 1.3. The methods presented in this work could contribute together to further improve operational oceanographic system in the Baltic Sea.

The measurements and the prediction methods can be used side by side so that the observations work as the basis of the hydrodynamic models that provide information on marine conditions for the initialisation and assimilation, as well as the validation and verification of the system's functionality (see, e.g. Le Traon 2013). Vice versa, the modelled results can be used for planning the observational network (Grayek et al. 2015).

Argo floats are widely used in the oceans. In this study the focus was on three aspects of the measurements taken by autonomous floats in the northern parts of the Baltic Sea: 1) piloting the floats in the Baltic Sea, 2) measuring and monitoring with the Argo floats and 3) analysing and using the GPS data further. 
Argo floats' strength compared to the ship-borne observations is that they are able to catch the seasonal variations of the temperature in the nearsurface layer, as well as the thermocline strength, due to the fact that they frequently measure during the summer when the peak temperatures appear. With the new automatic and real-time observations, it is possible to fill in some of the gaps in our understanding of the state of the sea, especially in regard to the temporal and spatial scales that are important to the biogeochemistry of the sea (McGillicuddy 2016). Combined with other methods, it is possible to make a closer study, for example, about climate change and its effects on a local scale. Sufficiently large amount of data from Argo floats could be combined with satellite data to create 3D observation field from the sea and use that as an initial field for models, in data assimilation or validation of the models. With the floats it is also possible to observe temperature and salinity changes in the deep layers and study the changes in stratification. This type of studies could be then combined with biogeochemical analysis of nutrient availability, upwellings and gas exchange, to name but a few examples.

The salinity range in both horizontal and vertical directions are, so far, better captured with the traditional CTD than the Argo measurements. There exists a horizontal salinity gradient in the Bothnian Sea which can be better observed with shipborne measurements than with Argo floats. The range of research ship operations is not limited by bathymetry and currents in the same manner as the trajectories of the Argo floats are. However, we can utilise the free-floating feature of the Argo floats to estimate water movements.

With ensembles the uncertainties of the forecasts can be shown and discussed in more detail. The upwellings have a great local impact on the marine environment as they change the physical conditions rapidly and bring nutrients to the euphotic zone (see, e.g. Lehtoranta et al. 2017). Upwelling events cool the surface water and affect the local weather (Sproson and Sahlée 2014). Prediction of these phenomena well in advance can help to serve society by increasing safety (see, e.g. Tonani et al. 2015, Hobday et al. 2016).

Society benefits from these aforementioned improvements. Hobday et al. (2016) showed that in the marine businesses there is a need for different forecast time spans ranging from nowcasts to climate-scale forecasts. The observations are an essential part of the operational systems as the data 
has numerous uses, as discussed in this work. The real-time observations tell the current status of the sea, and historical data sets reveal the changes in the marine environment. By knowing and understanding the hydrographical conditions in the sea, the alleviation of the negative human impact on the environment is possible.

\subsubsection{Observational methods}

Argo floats can measure the salinity and temperature profiles and currents at the diving depth on a temporal scale of hours. In the Bothnian Sea the time scales for current estimates need to be evaluated carefully, because the surface drift becomes dominant in very short cycle lengths. The surface currents affect floats' movement and the exact amount of the surface drift remains unknown. The order of magnitude can be estimated already, but in the future, the methods for removing the surface currents from the results can be developed. The methods for removing the surface drift could be, for example, to record the location more often while on the surface. The methods for evaluating the effect of mesoscale events on temperature and salinity observations, as well as on trajectories, are developed for the North Atlantic by simulating the Argo array with a numerical model (Kamenkovich et al. 2011). This implies that there is a growing need for careful planning of missions. The best and densest measurement interval for scalar measurement in the water column, such as temperature and salinity, is probably not the best for the vector measurements, such as velocity, as the portion of the surface drift increases.

With Argo floats it is possible to measure the water column in the deep areas of the Baltic Sea. In the Bothnian Sea's and Gotland Sea's deeps, the currents keep the floats in the same area and away from the coast, which extends the mission length. However, this also limits the use of the Argo floats, as they do not move actively so they cannot be directed anywhere else than where the winds and currents move them, and thus in practice, they cannot measure the whole basin. On the temporal scale the measurements cover a whole year cycle. So far the winter measurements have been sparse and the ice-avoidance technology has been tested. However, in the oceans the Argos are routinely measuring under ice (Wong and Riser 2013) and the test results from the Bothnian Sea and Bothnian Bay floats are promising. 
The Argo drifting depth is decided by the pilot. This decision is typically based on marine charts and the available bathymetry. Unfortunately the existing data for remote areas is sparse and sometimes inaccurate. This leads to collisions with the bottom and some unknown distance between the bottom and the drifting depth is not included in the profile measurements. Also, the surface data is not available due to the present sensor technology, which shuts the CTD pump down at approximate 4 dbar pressure.

The Argo data sent is real-time quality controlled (RTQC) by Coriolis Argo data centre (http://www.coriolis.eu.org). This procedure is similar with deep ocean Argo data. The delayed mode quality control (DMQC) methods for the deep ocean Argo data matured during the Argo project and their purpose was to ensure that the data was free from all detectable errors and biases (Gaillard et al. 2009). However, the DMQC methodology for Argo data from shallow, marginal seas is still under development.

With Argo floats it is possible to collect spatially and temporally dense observation series, which could contribute to climate modelling. Balmaseda and Anderson (2009) concluded that all the available data from ocean observing systems contribute to the skill of the seasonal forecast when used for initialising the forecast.

\subsubsection{The ensemble forecasting system}

Ensemble forecasts are a computationally time- and storage space-consuming way of forecasting. Compared to deterministic forecasting it is possible to gain more information about the uncertainties, but the price in this case is that the computational time and storage space needs are 50 times larger than those required for a deterministic forecast. This is also something to consider when planning to have more dense computational grids and more computationally intensive methods.

The ensemble forecasting system was analysed in Publication IV. From those results we may assume that there are some limitations to the forecasting system. The produced ensembles are somewhat too narrow so they do not detect all the events. There are some possible explanations for this: the initial conditions of the sea do not include information about the errors in the initial values. Therefore the forecast cannot take into account this uncertainty about the initial state of the sea. Also, too large vertical mixing together with a coarse resolution, can potentially cause, for example, 
incorrect forecasting of the formation of the sub-thermoclines during the summer and therefore only the large-scale features of the upwelling events can be detected. According to the results of the Leutbecher (2018) the number of ensemble member in this study can be regarded to be sufficient for operational purposes.

The wind forcing has a great impact on the quality of the ocean forecasts globally and the quality of the atmospheric forcings should be also improved (Treguier et al. 2017).

\section{Resolution}

Since the upwelling as a meso-scale phenomenon is also scaled by the baroclinic Rossby radius, the grid size should be of such an order (or even finer) (Lehmann and Myrberg 2008). Andrejev et al. (2011) and Lindow (1997) showed that the resolution for hydrodynamic models should be in order of half or even one-third of local baroclinic Rossby radius. In this study the spatial resolution of the BALECO model was $6 \mathrm{NM}$ (around $11.1 \mathrm{~km}$ ), which is in the upper limit of the baroclinic Rossby radius in the Baltic Sea (Alenius et al. 2003), and therefore the phenomena were not described to their full extent. However, as the purpose of this work was not to study the upwelling as such but to study the ensemble prediction system, the resolution was considered to be suitable as it was able to predict upwelling events, although the extent and magnitude were not fully described. To be able to produce mesoscale phenomena in detail in the Bothnian Sea the horizontal resolution should be in order of $1 \mathrm{~km} \times 1 \mathrm{~km}$.

\section{The threshold limits for probability forecasts}

In Publication IV the threshold limit for an upwelling was set to be $1^{\circ} \mathrm{C} /$ day (Lehmann and Myrberg 2008). On the one hand, it is unlikely that such a change in temperature would be produced by other phenomena, such as cold air advection, especially during the summer. On the other hand, this limit is still low enough to assure that important upwelling events are not missed.

In Publication V the chlorophyll-a concentration threshold value was set to $2 \mathrm{mg} \mathrm{m}^{-3}$ as a limit for a potentially visible cyanobacterial occurrence. In practice there is no such limit or standard, especially because the HAB observations are based on visual approximation. However, some studies have measured the chlorophyll-a concentration during a cyanobacterial bloom. 
Kutser (2006) suggested that blooming can be defined as a chlorophyll-a concentration exceeding $4 \mathrm{mg} \mathrm{m}^{-3}$. Mazur-Marzec (2006) found that the chlorophyll-a concentration was about $10 \mathrm{mg} \mathrm{m}^{-3}$ or more during blooming in the Gulf of Gdańsk in the summer of 2004. However, Karlson et al. (2008) did not find any correlation between satellite based observation and microscope analysis of the cyanobacteria accumulations. In this work the evaluation was based on the best available operational HAB data of the area, which was composite of satellite and visual data, therefore including uncertainties from the both datasets. Taking into account the uncertainties in the nitrogen-chlorophyll conversion, $2 \mathrm{mg} \mathrm{m}^{-3}$ is a conservative limit for a level of biomass that could be perceived as a harmful or nuisance bloom.

\subsection{Future work}

In changing climate, the need for theoretical framework and models which can cope with large amount of data is complementary to dense and highquality observations. Ruhl et al. (2011) concluded that physical parameters can be forecasted fairly well, but even more specific tools are needed, for example, in food web modelling and forecasts for marine ecosystem variables. The ecosystem modelling of the Baltic Sea has not yet reached a state in which it could answer the majority of the requirements for the EU MSFD (Tedesco et al. 2016). Ensemble forecasting systems are an essential tool in operational oceanography, serving numerous purposes such as sustainable blue growth and future planning. In the future extreme weather events will potentially be more common, and therefore, ensemble forecasts can also help mitigate the effects of these events (She et al. 2016).

The observational and computational methods are developing fast. Argo data has already been used to evaluate models in the Bothnian Sea (Westerlund and Tuomi 2016). In the future the computational capacity will increase and that will enable several new improvements, not only in spatial and temporal resolution but also in the computational methods themselves, such as those used in self-organizing maps and machine learning. In the future it is possible to use models with more complex topology and ecological models. This complexity requires better understanding of the processes, as well as better methods for assimilation, improvements of the initial 
fields and also methods for data analysis and management (see, e.g. Dickey 2003, Axell and Liu 2016).

Globally, high quality observations of salinity and temperature are combined statistically with frequent and lower-accuracy satellite measurements to produce 3D temperature and salinity fields at high temporal and spatial resolutions (Guinehut et al. 2012). Furthermore, the combined systems' ability to reconstruct mesoscale phenomena has been evaluated (Barceló-Llull et al. 2018). The ability of the Argo fleet to work as a part of observational systems has also been analysed by statistical methods and models (Grayek et al. 2015). The 3D fields have been tested lately for forecast data assimilation in the Baltic Sea (Axell and Liu 2016).

The measurement and battery technology is developing fast. With the more powerful batteries the floats can carry more sensors, including altimeter to prevent the bottom hits and adjust the diving depth in relation to the bottom. The more frequent GPS connections from the surface help to assess the surface drift. The CTD technology is developing, and it enables achieving temperature and salinity data from the whole water column, from the bottom to the surface. The interconnection with other observational platforms need to be considered. For example, the role of gliders was analysed by Liblik et al. (2016). 
Discussion 


\section{Conclusions}

The measurements are a basis for understanding the sea environment. With models it is possible to take a leap forward and try to understand the sea as a whole. Models can be used for forecasting forthcoming events and states. In real life, there has to be a tight connection between the theoretical framework (the model data) and reality (the observations), and the models help us to see further while the observations root our knowledge in reality as far as it is possible.

Even though the observations create the ground truth for all marine analyses, it must be pointed out that observations also have limitations. Measurements do not cover the whole sea and the data has systematic and random errors. The magnitude varies from method to method. This work presents the sources of the uncertainties in Argo observations as well as in forecasts.

The new floats fill the gaps in the observational network of the Baltic Sea in the remote areas. It is possible to achieve observations of small-scale phenomena including high speed currents, and salinity and temperature anomalies in the water columns. With these measurements it is possible to study extreme and/or short-term events that could not have been detected with traditional measurement devices and/or measurement frequencies or with relatively low costs. The floats can be used also for monitoring conditions in the sea and for detecting changes in yearly and, in the future, in decadal scale. The extreme events can be observed during the bad weather that commonly prevents traditional ship-borne observations.

In this thesis new data for analysing the deep currents in a fairly shallow and stratified sea with a non-stationary deep water drifter was used and analysis methods were developed. The results showed that the current estimates from the Argo data produce values on the same magnitude as 
the values with traditional measurement devices. Furthermore, from the Argo data it is possible to detect and analyse the circumstances in which the current speeds were exceptionally high as well as analyse the current field in the deep areas with some limitations.

In this thesis, probability-based forecasting for upwelling phenomena was presented and the length of reliable forecasts were analysed. The analysis showed that up-to-a-week forecasts were accurate and detected large upwellings almost every time. In the longer forecast range the predictability of the forecast deteriorated and the over two-week forecasting system presented in this study was very weak for detecting upwellings.

However, the forecast span of the length of week or more is enough to, for example, prepare for emerging, scientifically interesting events. From the point of view of forecasting, the development of upwelling events and their effect on local weather can be followed more closely.

The hydrodynamics and thermodynamics are important factors of the ecosystem in the sea. As seen in this work, there are a lot of uncertainties in the dynamics alone. The uncertainties in modelling of marine biogeochemistry were studied and an ecological model was used to predict the HABs in the Baltic Sea. The ecosystem model itself had uncertainties added to those in the hydrodynamic model, and therefore many simplifications were made. However, the study showed that it was possible to produce $\mathrm{HAB}$ predictions based on the computational model and present the uncertainties in an understandable manner.

In modern marine science, the observations and computational models are tightly interconnected so that observations work as the initial and boundary condition for the models and forecasts. In the optimal situation they are assimilated in the forecasts and used for validation and verification. In an opposite way, measurement networks and campaigns can be designed with models and it is possible to gain a better understanding of the essential processes when they can be observed at the time they occur and not when the measurements are scheduled. 


\section{References}

Aksnes, D.L., Ulvestad, K.B., Baliño, B.M., Berntsen, J., Egge, J.K., Svendsen, E., 1995. Ecological modelling in coastal waters: towards predictive physicalchemical-biological simulation models. Ophelia 41, 5-36.

Alenius, P., 1993. Finnish Eulerian current measurements, in: Murthy, R., Håkansson, B., Alenius, P. (Eds.), The Gulf of Bothnia Year 1991. Physical transport experiments. Swedish Meteorological and Hydrological Institute, Norrköping. number 15 in SMHI Reports Oceanography. chapter 3, pp. 30-40.

Alenius, P., Nekrasov, A., Myrberg, K., 2003. Variability of the baroclinic Rossby radius in the Gulf of Finland. Continental Shelf Research 23, 563-573.

Andersen, J.H., Carstensen, J., Conley, D.J., Dromph, K., Fleming-Lehtinen, V., Gustafsson, B.G., Josefson, A.B., Norkko, A., Villnäs, A., Murray, C., 2017. Long-term temporal and spatial trends in eutrophication status of the Baltic Sea. Biological Reviews 92, 135-149. URL: https://onlinelibrary.wiley.com/doi/abs/10.1111/brv.12221, doi:10.1111/brv.12221, arXiv: https://onlinelibrary.wiley.com/doi/pdf/10.1111/brv . 12221.

Anderson, J.L., 1996. A method for producing and evaluating probabilistic forecasts from ensemble model integrations. Journal of Climate 9, 1518-1530.

Andersson, A., Meier, H.E.M., Ripszam, M., Rowe, O., Wikner, J., Haglund, P., Eilola, K., Legrand, C., Figueroa, D., Paczkowska, J., Lindehoff, E., Tysklind, M., Elmgren, R., 2015. Projected future climate change and Baltic Sea ecosystem management. AMBIO 44, 345-356. URL: https://doi.org/10.1007/ s13280-015-0654-8, doi:10.1007/s13280-015-0654-8.

Andrejev, O., Myrberg, K., Alenius, P., Lundberg, P.A., 2004. Mean circulation and water exchange in the Gulf of Finland-a study based on three-dimensional modelling. Boreal Environment Research 9, 1-16.

Andrejev, O., Soomere, T., Sokolov, A., Myrberg, K., 2011. The role of the spatial resolution of a three-dimensional hydrodynamic model for marine transport risk assessment. Oceanologia 53, 309 - 334. URL: http://www.sciencedirect.com/ science/article/pii/S0078323411500442, doi:https ://doi . org/10.5697/oc.53- 1-TI. 309.

Axell, L., Liu, Y., 2016. Application of 3-D ensemble variational data assimilation to a Baltic Sea reanalysis 1989-2013. Tellus A: Dynamic Meteorology and Oceanography 68, 24220. URL: https://doi.org/10.3402/tellusa.v68.24220, doi:10. 3402/tellusa.v68.24220, arXiv: https://doi.org/10.3402/tellusa. v68. 24220. 
BACC II, Author Team (Eds.), 2015. Second assessment of climate change for the Baltic Sea Basin. SpringerOpen. doi:https ://doi .org/10.1007/978- 3- 319-16006 - 1.

Balmaseda, M., Anderson, D., 2009. Impact of initialization strategies and observations on seasonal forecast skill. Geophysical Research Letters 36. URL: https:/agupubs.onlinelibrary. wiley.com/doi/abs/10.1029/2008GL035561, doi:10.1029/2008GL035561, arXiv: https: //agupubs. onlinelibrary.wiley.com/doi/pdf/10.1029/2008GL035561.

Barceló-Llull, B., Pascual, A., Mason, E., Mulet, S., 2018. Comparing a multivariate global ocean state estimate with high-resolution in situ data: An anticyclonic intrathermocline eddy near the Canary Islands. Frontiers in Marine Science 5, 66. URL: https://www.frontiersin.org/article/10.3389/fmars.2018.00066, doi:10.3389/fmars. 2018.00066.

Barker, P.M., Dunn, J.R., Domingues, C.M., Wijffels, S.E., 2011. Pressure sensor drifts in Argo and their impacts. Journal of Atmospheric and Oceanic Technology 28, 1036-1049.

Bell, M.J., Guymer, T.H., Turton, J.D., MacKenzie, B.A., Rogers, R., Hall, S.P., 2013. Setting the course for UK operational oceanography. Journal of Operational Oceanography 6, 1-15. URL: https:// doi.org/10.1080/1755876X.2013.11020146, doi:10.1080/1755876X.2013.11020146, arXiv: https://doi.org/10.1080/1755876X.2013.11020146.

Bianchi, T.S., Engelhaupt, E., Westman, P., Andrén, T., Rolff, C., Elmgren, R., 2000. Cyanobacterial blooms in the Baltic Sea: Natural or human-induced? Limnology and Oceanography 45, 716-726. URL: https://aslopubs.onlinelibrary. wiley.com/doi/abs/10.4319/1o.2000.45.3.0716, doi:10 . 4319/lo . 2000 . 45 . 3 . 0716.

Boss, E., Swift, D., Taylor, L., Brickley, P., Zaneveld, R., Riser, S., Perry, M.J., Strutton, P.G., 2008. Observations of pigment and particle distributions in the western North Atlantic from an autonomous float and ocean color satellite. Limnology and Oceanography 53, 2112-2122. URL: https://aslopubs.onlinelibrary. wiley.com/doi/abs/10.4319/lo.2008.53.5_part_2.2112, doi:10.4319/lo.2008.53.5\ _part\_2.2112.

Boyer, T., Antonov, J., Garcia, H., Johnson, D., Locarnini, R., Mishonov, A., Pitcher, M., Baranova, O., Smolyar, I., 2006. World Ocean Database 2005. NOAA Atlas NESDIS 60, U.S Government Printing Office, Washington D.C. Version WOD 2001.

Burchard, H., Bolding, K., Villarreal, M.R., 2004. Three-dimensional modelling of estuarine turbidity maxima in a tidal estuary. Ocean Dynamics 54, 250-265. URL: https://doi.org/10.1007/s10236-003-0073-4, doi:10. 1007/s10236- 003- 0073- 4.

Burchard, H., Janssen, F., Bolding, K., Umlauf, L., Rennau, H., 2009. Model simulations of dense bottom currents in the Western Baltic Sea. Continental Shelf Research 29, 205 - 220. URL: http://www.sciencedirect.com/science/article/ pii/S0278434307002920, doi:https ://doi.org/10.1016/j.csr.2007.09.010. physics of Estuaries and Coastal Seas: Papers from the PECS 2006 Conference.

Choi, M., Chung, H., Yamaguchi, H., Nagakawa, K., 2015. Arctic sea route path planning based on an uncertain ice prediction model. Cold Regions Science and Technology 109, 61 - 69. URL: http://www.sciencedirect.com/science/article/pii/ S0165232X14001748, doi:https : //doi .org/10.1016/j . coldregions . 2014 . 10.001. 
Dickey, T.D., 2003. Emerging ocean observations for interdisciplinary data assimilation systems. Journal of Marine Systems 40-41, 5 - 48. URL: http://www.sciencedirect.com/science/article/pii/S0924796303000113, doi:https: //doi.org/10.1016/S0924-7963(03)00011-3. the Use of Data Assimilation in Coupled Hydrodynamic, Ecological and Bio-geo-chemical Models of the Ocean. Selected papers from the 33rd International Liege Colloquium on Ocean Dynamics, held in Liege, Belgium on May 7-11th, 2001.

Dominicis, M.D., Falchetti, S., Trotta, F., Pinardi, N., Giacomelli, L., Napolitano, E., Fazioli, L., Sorgente, R., Haley Jr., P.J., J. Lermusiaux, P.F., Martins, F., Cocco, M., 2014. A relocatable ocean model in support of environmental emergencies. Ocean Dynamics 64, 667-688. URL: https://doi.org/10.1007/ s10236-014-0705-x, doi:10.1007/s10236-014-0705-x.

Donaldson, R., Dyer, R.M., Kraus, M.J., 1975. Objective evaluator of techniques for predicting severe weather events, in: Bulletin of the American Meteorological Society, AMER METEOROLOGICAL SOC 45 BEACON ST, BOSTON, MA 02108-3693. pp. 755-755.

Ebert, E.E., 2001. Ability of a poor man's ensemble to predict the probability and distribution of precipitation. Monthly Weather Review 129, 2461-2480.

Ehler, C., Douvere, F., 2009. Marine Spatial Planning: a step-by-step approach toward ecosystem-based management. IOC Manuals and Guides 53; ICAM Dossier 6, Unesco, Paris.

Elmgren, R., Blenckner, T., Andersson, A., 2015. Baltic Sea management: Successes and failures. AMBIO 44, 335-344. URL: https://doi.org/10.1007/ s13280-015-0653-9, doi:10.1007/s13280-015-0653- 9.

European Parliament and Council, 2008. Directive 2008/56/EC of the European Parliament and of the Council of 17 june 2008 establishing a framework for community action in the field of marine environmental policy (Marine Strategy Framework Directive). Http://data.europa.eu/eli/dir/2008/56/oj.

Fennel, W., Seifert, T., Kayser, B., 1991. Rossby radii and phase speeds in the Baltic Sea. Continental Shelf Research 11, 23-36.

Finni, T., Kononen, K., Olsonen, R., Wallström, K., 2001. The history of cyanobacterial blooms in the Baltic Sea. AMBIO: A Journal of the Human Environment $30,172-178$.

Finnish Research Infrastructure Committee, 2013. Finland's strategy and roadmap for research infrastructures 2014-2020. http://www.aka.fi/ globalassets/awanhat/documents/firi/tutkimusinfrastruktuurien_strategia_ ja_tiekartta_2014_en.pdf. Accessed 13.12.2018.

Fleming-Lehtinen, V., Andersen, J.H., Carstensen, J., Łysiak-Pastuszak, E., Murray, C., Pyhälä, M., Laamanen, M., 2015. Recent developments in assessment methodology reveal that the Baltic Sea eutrophication problem is expanding. Ecological Indicators 48, 380 - 388. URL: http://www.sciencedirect.com/science/ article/pii/S1470160X1400377X, doi:https://doi.org/10.1016/j . ecolind.2014.08. 022.

Flemming, N.C., 2002. Strategic planning for operational oceanography, in: Pinardi, N., Woods, J. (Eds.), Ocean forecasting: conceptual basis and applications. Springer Science \& Business Media, Berlin, pp. 1-15. 
Flynn, K.J., McGillicuddy, D.J., 2018. Modeling marine harmful algal blooms: Current status and future prospects, in: Shumway, S.E., Burkholder, J.M., Morton, S.L. (Eds.), Harmful Algal Blooms. Wiley-Blackwell. chapter 3, pp. 115-134. URL: https://onlinelibrary. wiley.com/doi/abs/10.1002/9781118994672.ch3, doi:10.1002/9781118994672.ch3, arXiv: https://onlinelibrary.wiley.com/doi/pdf/10.1002/9781118994672.ch3.

Fonselius, S., Valderrama, J., 2003. One hundred years of hydrographic measurements in the Baltic Sea. Journal of Sea Research 49, 229-241.

Gaillard, F., Autret, E., Thierry, V., Galaup, P., Coatanoan, C., Loubrieu, T., 2009. Quality control of large Argo datasets. Journal of Atmospheric and Oceanic Technology 26, 337-351. URL: https://doi.org/10.1175/2008JTECHO552.1, doi:10.1175/2008JTECH0552.1, arXiv: https://doi.org/10.1175/2008JTECH0552.1.

Gill, A.E., 1982. Atmosphere-Ocean Dynamics. volume 30 of International Geophysics. Academic Press, San Diego, USA.

Golbeck, I., Li, X., Janssen, F., Brüning, T., Nielsen, J.W., Huess, V., Söderkvist, J., Büchmann, B., Siiriä, S.M., Vähä-Piikkiö, O., Hackett, B., Kristense, N.M., Engedahl, H., Blockley, E., Sellar, A., Lagemaa, P., Ozer, J., Legrand, S., Ljungemyr, P., Axell, L., 2015. Uncertainty estimation for operational ocean forecast products - a multi-model ensemble for the North Sea and the Baltic Sea. Ocean Dynamics 65, 1603-1631.

Gould, J., Roemmich, D., Wijffels, S., Freeland, H., Ignaszewsky, M., Jianping, X., Pouliquen, S., Desaubies, Y., Send, U., Radhakrishnan, K., Takeuchi, K., Kim, K., Danchenkov, M., Sutton, P., King, B., Owens, B., Riser, S., 2004. Argo profiling floats bring new era of in situ ocean observations. Eos, Transactions American Geophysical Union 85, 185-191. URL: https://agupubs.onlinelibrary. wiley.com/doi/abs/10.1029/2004EO190002, doi:10.1029/2004E0190002, arXiv: https://agupubs . onlinelibrary.wiley.com/doi/pdf/10. 1029/2004E0190002.

Grayek, S., Stanev, E.V., Schulz-Stellenfleth, J., 2015. Assessment of the Black Sea observing system. A focus on 2005-2012 Argo campaigns. Ocean Dynamics 65, 1665-1684. URL: https://doi.org/10.1007/s10236-015-0889-8, doi:10.1007/ s10236- 015 - $0889-8$.

Groetsch, P.M.M., Simis, S.G.H., Eleveld, M.A., Peters, S.W.M., 2016. Spring blooms in the Baltic Sea have weakened but lengthened from 2000 to 2014 . Biogeosciences 13, 4959-4973. URL: https://www.biogeosciences.net/13/4959/ 2016/, doi:10.5194/bg-13-4959- 2016.

Guinehut, S., Dhomps, A.L., Larnicol, G., Le Traon, P.Y., 2012. High resolution 3$\mathrm{D}$ temperature and salinity fields derived from in situ and satellite observations. Ocean Science 8, 845-857. URL: https://www.ocean-sci.net/8/845/2012/, doi:10. 5194/os - 8- 845- 2012.

Haapala, J., 1994. Upwelling and its influence on nutrient concentration in the coastal area of the Hanko Peninsula, entrance of the Gulf of Finland. Estuarine, Coastal and Shelf Science 38, 507-521.

Haapala, J., Alenius, P., 1994. Temperature and salinity statistics for the northern Baltic Sea 1961-1990. Finnish Marine Research , 51-121. 
Håkansson, B., Alenius, P., Brydsten, L., 1996. Physical environment in the Gulf of Bothnia. Ambio , 5-12.

Hamill, T.M., 2001. Interpretation of rank histograms for verifying ensemble forecasts. Monthly Weather Review 129, 550-560.

Hamill, T.M., Colucci, S.J., 1997. Verification of Eta-RSM shortrange ensemble forecasts. Monthly Weather Review 125, 13121327. URL: https://doi.org/10.1175/1520-0493(1997)125<1312: VOERSR>2.0.CO;2, doi:10.1175/1520-0493 (1997) 125<1312: V0ERSR>2 . 0 . C0 ; 2 , arXiv: https://doi.org/10.1175/1520-0493(1997) 125<1312:V0ERSR>2 . 0. C0; 2.

Heisler, J., Glibert, P., Burkholder, J., Anderson, D., Cochlan, W., Dennison, W., Dortch, Q., Gobler, C., Heil, C., Humphries, E., Lewitus, A., Magnien, R., Marshall, H., Sellner, K., Stockwell, D., Stoecker, D., Suddleson, M., 2008. Eutrophication and harmful algal blooms: A scientific consensus. Harmful Algae 8, 3 13. URL: http://www.sciencedirect.com/science/article/pii/S1568988308001066, doi:https://doi.org/10.1016/j.hal.2008.08.006. hABs and Eutrophication.

Hela, I., 1958. A hydrographical survey of the waters in the Åland Sea. Geophysica $6,219-242$.

HELCOM, 2017. Manual for marine monitoring in the COMBINE programme of HELCOM. Part C, Programme for monitoring of eutrophication and its effects, Annex C-2, Technical Annex I, HELCOM .

HELCOM, 2018a. Helcom maritime assessment 2018, Helsinki Comission (HELCOM) - Baltic Marine Environment Protection Commission.

HELCOM, 2018b. State of the Baltic Sea - second HELCOM holistic assessment 2011-2016, Helsinki Comission (HELCOM) - Baltic Marine Environment Protection Commission.

Hersbach, H., 2000. Decomposition of the continuous ranked probability score for ensemble prediction system. Weather and Forecasting 15, 559-570.

Hintze, J.L., Nelson, R.D., 1998. Violin plots: A box plot-density trace synergism. The American Statistician 52, 181-184.

HIRLAM-B, 2015. System documentation. Technical Report. HIRLAM consortium. URL: http://www.hirlam.org/.

Hobday, A.J., Spillman, C.M., Paige Eveson, J., Hartog, J.R., 2016. Seasonal forecasting for decision support in marine fisheries and aquaculture. Fisheries Oceanography 25, 45-56. URL: https: //onlinelibrary.wiley.com/doi/abs/10.1111/fog.12083, doi:10.1111/fog.12083, arXiv: https://onlinelibrary.wiley.com/doi/pdf/10.1111/fog. 12083.

Holtermann, P.L., Burchard, H., Gräwe, U., Klingbeil, K., Umlauf, L., 2014. Deep-water dynamics and boundary mixing in a nontidal stratified basin: A modeling study of the Baltic Sea. Journal of Geophysical Research: Oceans 119, 1465-1487. URL: https:/agupubs.onlinelibrary. wiley.com/doi/abs/10.1002/2013JC009483, doi:10.1002/2013JC009483, arXiv: https://agupubs . onlinelibrary.wiley. com/doi/pdf/10. 1002/2013JC009483. 
Hordoir, R., Axell, L., Höglund, A., Dieterich, C., Fransner, F., Gröger, M., Liu, Y., Pemberton, P., Schimanke, S., Andersson, H., Ljungemyr, P., Nygren, P., Falahat, S., Nord, A., Jönsson, A., Lake, I., Döös, K., Hieronymus, M., Dietze, H., Löptien, U., Kuznetsov, I., Westerlund, A., Tuomi, L., Haapala, J., 2018. NemoNordic: A NEMO based ocean model for Baltic \& North Seas, research and operational applications. Geoscientific Model Development Discussions 2018, 1-29. URL: https://www.geosci-model-dev-discuss.net/gmd-2018-2/, doi:10.5194/ gmd - 2018- 2 .

Hordoir, R., Axell, L., Löptien, U., Dietze, H., Kuznetsov, I., 2015. Influence of sea level rise on the dynamics of salt inflows in the Baltic Sea. Journal of Geophysical Research: Oceans 120, 6653-6668. URL: https://agupubs.onlinelibrary. wiley.com/doi/abs/10.1002/2014JC010642, doi:10.1002/2014Jc010642, arXiv: https://agupubs . onlinelibrary.wiley.com/doi/pdf/10.1002/2014JC010642.

Hordoir, R., Dieterich, C., Basu, C., Dietze, H., Meier, H., 2013. Freshwater outflow of the Baltic Sea and transport in the Norwegian current: A statistical correlation analysis based on a numerical experiment. Continental Shelf Research 64, 1-9. doi:http://dx.doi.org/10.1016/j.csr.2013.05.006.

Howes, E., Joos, F., Eakin, M., Gattuso, J.P., 2015. An updated synthesis of the observed and projected impacts of climate change on the chemical, physical and biological processes in the oceans. Frontiers in Marine Science 2, 36. URL: https://www.frontiersin.org/article/10.3389/fmars.2015.00036, doi:10.3389/fmars. 2015.00036.

IOC, SCOR, IAPSO, 2010. The international thermodynamic equation of seawater - 2010: Calculation and use of thermodynamic properties. Number 56 in Intergovernmental Oceanographic Commission, Manuals and Guides, UNESCO.

Jaanus, A., Andersson, A., Olenina, I., Toming, K., Kaljurand, K., 2011. Changes in phytoplankton communities along a north-south gradient in the Baltic Sea between 1990 and 2008. Boreal Environment Research 16 (suppl. A), 191-208.

Johansson, M., Boman, H., Kahma, K.K., Launiainen, J., 2001. Trends in sea level variability in the Baltic Sea. Boreal Environment Research 6, 159-180.

Johansson, M.M., Pellikka, H., Kahma, K.K., Ruosteenoja, K., 2014. Global sea level rise scenarios adapted to the Finnish coast. Journal of Marine Systems 129, 35 - 46. URL: http://www.sciencedirect.com/science/article/pii/ S0924796312001686, doi:https://doi.org/10.1016/j . jmarsys.2012.08.007.

Johnson, K.S., Berelson, W.M., Boss, E.S., Chase, Z., Claustre, H., Emerson, S.R., Gruber, N., Körtzinger, A., Perry, M.J., Riser, S.C., 2009. Observing biogeochemical cycles at global scales with profiling floats and gliders: prospects for a global array. Oceanography 22, 216-225.

Jolliffe, I.T., Stephenson, D.B., 2003. Forecast Verification - A Practitioner's guide in Atmospheric Science. John Wiley and sons, The Atrium, Chichester, West Sussex PO19 8SQ, England.

Kahma, K., Pettersson, H., Tuomi, L., 2003. Scatter diagram wave statistics from the northern Baltic Sea. MERI-Report Series of the Finnish Institute of Marine Research 49, 15-32. 
Kahru, M., Håkansson, B., Rud, O., 1995. Distributions of the sea-surface temperature fronts in the Baltic Sea as derived from satellite imagery. Continental Shelf Research 15, 663 - 679. URL: http://www.sciencedirect.com/science/article/ pii/0278434394E0030P, doi:http://dx. doi .org/10. 1016/0278 - 4343(94) E0030-P.

Kamenkovich, I., Cheng, W., Schmid, C., Harrison, D.E., 2011. Effects of eddies on an ocean observing system with profiling floats: Idealized simulations of the Argo array. Journal of Geophysical Research: Oceans 116. URL: https://agupubs.onlinelibrary. wiley.com/doi/abs/10.1029/2010JC006910, doi:10.1029/2010Jc006910, arXiv: https://agupubs . onlinelibrary.wiley.com/doi/pdf/10.1029/2010Jc006910.

Karlson, B., Eilola, K., Hansson, M., 2008. Cyanobacterial blooms in the Baltic Sea: correlating bloom observations with environmental conditions, in: Proc 13th Int Conf on Harmful Algae, pp. 247-252.

Karpechko, A.Y., Peterson, K.A., Scaife, A.A., Vainio, J., Gregow, H., 2015. Skilful seasonal predictions of Baltic Sea ice cover. Environmental Research Letters 10, 044007. URL: http://stacks.iop.org/1748-9326/10/i=4/a=044007.

Kiiltomäki, A., 2008. Development of the Baltic Sea indicator report by Alg@line measurements and BalEco model results. Master's thesis. University of Helsinki.

Kikas, V., Lips, U., 2016. Upwelling characteristics in the Gulf of Finland (Baltic Sea) as revealed by Ferrybox measurements in 2007-2013. Ocean Science 12, 843-859. URL: https://www.ocean-sci.net/12/843/2016/, doi:10.5194/ os - $12-843-2016$.

Klatt, O., Boebel, O., Fahrbach, E., 2007. A profiling float's sense of ice. Journal of Atmospheric and Oceanic Technology 24, 13011308. URL: https://doi.org/10.1175/JTECH2026.1, doi:10.1175/JTECH2026.1, arXiv:https://doi.org/10.1175/JTECH2026.1.

Korpinen, S., Laamanen, M., Heiskanen, A.S., Ahola, M., Alenius, P., Attila, J., et al. (Eds.), 2015. Suomen Merenhoidon Seurantakäsikirja. Ministry of the Environment, 160 (in Finnish). Http://www.ymparisto.fi/download/noname/\%7BECF9A983-AC50-4DABB237-D7EA3A09664B\%7D/103978.

Korpinen, S., Laamanen, M., Suomela, J., Paavilainen, P., Lahtinen, T., Ekebom, J. (Eds.), 2018. Suomen meriympäristön tila 2018, Suomen ympäristökeskus SYKE. Grano, Helsinki. ISBN 978-952-11-4968-9 (PDF).

Körtzinger, A., Schimanski, J., Send, U., Wallace, D., 2004. The ocean takes a deep breath. Science 306, 1337-1337. URL: http: //science.sciencemag.org/content/306/5700/1337, doi:10.1126/science.1102557, arXiv: http://science. sciencemag. org/content/306/5700/1337. full. pdf.

Kowalewski, M., Ostrowski, M., 2005. Coastal up-and downwelling in the southern Baltic. Oceanologia 47, 453-475.

Krapivin, V.F., Varotsos, C.A., 2016. Modelling the $\mathrm{CO}_{2}$ atmosphere-ocean flux in the upwelling zones using radiative transfer tools. Journal of Atmospheric and Solar-Terrestrial Physics 150-151, 47 - 54. URL: http://www.sciencedirect. com/science/article/pii/S1364682616302425, doi:https ://doi .org/10.1016/j . jastp. 2016.10.015. 
Krauss, W., Brügge, B., 1990. Wind-produced water exchange between the deep basins of the Baltic Sea. Journal of Physical Oceanography 21, 373-384.

Kuosa, H., Fleming-Lehtinen, V., Lehtinen, S., Lehtiniemi, M., Nygård, H., Raateoja, M., Raitaniemi, J., Tuimala, J., Uusitalo, L., Suikkanen, S., 2017. A retrospective view of the development of the Gulf of Bothnia ecosystem. Journal of Marine Systems 167, 78 - 92. URL: http://www. sciencedirect.com/science/article/pii/S0924796316304006, doi:https://doi.org/ 10.1016/j . jmarsys. 2016.11.020.

Kutser, T., 2006. Monitoring cyanobacterial blooms by satellite remote sensing. Estuarine, Coastal and Shelf Science 67, 303-312.

Laamanen, M. (Ed.), 2016. Suomen Merenhoitosuunnitelman Toimenpideohjelma 2016 - 2021 (Programme of Measures for the Development and Implementation of the Marine Strategy in Finland 2016 - 2021), Reports of the Ministry of the Environment 5/2016, Helsinki.

Lagemaa, P., 2012. Operational forecasting in Estonian marine waters. Ph.D. thesis. TALLINN UNIVERSITY OF TECHNOLOGY.

Large, W.G., Yeager, S.G., 2004. Diurnal to decadal global forcing for ocean and sea-ice models: the data sets and flux climatologies. NCAR Technical Note, NCAR/TN-460+STR, CGD Division of the National Center for Atmospheric Research. URL: http://dx.doi.org/10.5065/D6KK98Q6.

Le Traon, P.Y., 2013. From satellite altimetry to Argo and operational oceanography: three revolutions in oceanography. Ocean Science , 901-915.

Lehmann, A., Krauß, W., Hinrichsen, H.H., 2001. Effects of remote and local atmospheric forcing on circulation and upwelling in the Baltic Sea. Tellus A: Dynamic Meteorology and Oceanography 54, 299-316.

Lehmann, A., Myrberg, K., 2008. Upwelling in the Baltic Sea - a review. Journal of Marine Systems 74, S3 - S12. URL: http://www.sciencedirect.com/ science/article/pii/S0924796308002492, doi:https://doi.org/10.1016/j.jmarsys. 2008. 02.010. baltic Sea Science Congress 2007.

Lehmann, A., Myrberg, K., Höflich, K., 2012. A statistical approach to coastal upwelling in the baltic sea based on the analysis of satellite data for 1990-2009. Oceanologia 54, 369-393.

Lehtoranta, J., Savchuk, O.P., Elken, J., Dahlbo, K., Kuosa, H., Raateoja, M., Kauppila, P., Räike, A., Pitkänen, H., 2017. Atmospheric forcing controlling inter-annual nutrient dynamics in the open Gulf of Finland. Journal of Marine Systems 171, 4 - 20. URL: http://www.sciencedirect.com/science/article/pii/ S0924796317300659, doi:https://doi.org/10.1016/j . jmarsys.2017.02.001. towards a healthier Gulf of Finland - " results of the International Gulf of Finland Year 2014.

Lentz, W., 1971. Monatskarte der Temperatur der Ostsee dargestellt für verschiedene Tiefenhorisonte [Monthly maps of the temperature of the Baltic Sea for different depths]. Deutsche Hydrographische Zeitschrift, Ergänzungshäft Reihe B , 1-148.

Leppäranta, M., Myrberg, K., 2009. Physical Oceanography of the Baltic Sea. 1 ed., Praxis Publishing Ltd, Chichester, UK. 
Leutbecher, M., 2018. Ensemble size: How suboptimal is less than infinity? Quarterly Journal of the Royal Meteorological Society URL: https://rmets.onlinelibrary.wiley.com/doi/abs/10.1002/qj.3387, doi:10.1002/qj. 3387, arXiv:https://rmets.onlinelibrary.wiley.com/doi/pdf/10.1002/qj.3387.

Leutbecher, M., Palmer, T., 2008. Ensemble forecasting. Journal of Computational Physics 227, 3515-3539.

Lévy, M., Ferrari, R., Franks, P.J.S., Martin, A.P., Riviére, P., 2012. Bringing physics to life at the submesoscale. Geophysical Research Letters 39. URL: https://agupubs.onlinelibrary. wiley.com/doi/abs/10.1029/2012GL052756, doi:10.1029/2012GL052756, arXiv: https://agupubs. onlinelibrary. wiley. com/doi/pdf/10. 1029/2012GL052756.

Liblik, T., Karstensen, J., Testor, P., Alenius, P., Hayes, D., Ruiz, S., Heywood, K., Pouliquen, S., Mortier, L., Mauri, E., 2016. Potential for an underwater glider component as part of the Global Ocean Observing System. Methods in Oceanography 17, 50 - 82. URL: http://www.sciencedirect.com/science/article/ pii/S2211122016300056, doi:https://doi.org/10.1016/j .mio.2016.05.001. special section on Novel instrumentation in Oceanography: a dedication to Rob Pinkel.

Lindow, H., 1997. Experimentelle Simulationen windangeregter dynamischer Muster in hochauflösenden numerischen Modellen. Institut für Ostseeforschung Warnemünde.

Lips, I., Lips, U., 2008. Abiotic factors influencing cyanobacterial bloom development in the Gulf of Finland (Baltic Sea). Hydrobiologia 614, 133-140. URL: https://doi.org/10.1007/s10750-008-9449-2, doi:10. 1007/s10750- 008- 9449 - 2.

Lips, I., Lips, U., Liblik, T., 2009. Consequences of coastal upwelling events on physical and chemical patterns in the central Gulf of Finland (Baltic Sea). Continental Shelf Research 29, 1836 - 1847. URL: http://www.sciencedirect. com/science/article/pii/S0278434309002064, doi:https ://doi .org/10.1016/j .csr. 2009.06.010.

Lips, U., Kikas, V., Liblik, T., Lips, I., 2016. Multi-sensor in situ observations to resolve the sub-mesoscale features in the stratified Gulf of Finland, Baltic Sea. Ocean Science 12, 715-732. URL: https://www.ocean-sci.net/12/715/2016/, doi:10.5194/os-12-715- 2016.

Lisitzin, E., 1974. Sea-level changes. volume 8. Elsevier Scientific Publishing Company, Amsterdam.

Liu, Y., Weisberg, R.H., Hu, C., Zheng, L., 2011. Tracking the Deepwater Horizon oil spill: A modeling perspective. Eos, Transactions American Geophysical Union 92, 45-46. URL: https://agupubs.onlinelibrary. wiley.com/doi/abs/10.1029/2011EO060001, doi:10.1029/2011E0060001, arXiv: https://agupubs. onlinelibrary.wiley.com/doi/pdf/10. 1029/2011E0060001.

Lorenz, E.N., 1965. A study of the predictability of a 28-variable atmospheric model. Tellus 17, 321-333. URL: https:/onlinelibrary.wiley.com/doi/abs/ 10.1111/j.2153-3490.1965.tb01424.x, doi:10.1111/j.2153-3490.1965.tb01424.x, arXiv: https://onlinelibrary.wiley. com/doi/pdf/10.1111/j .2153-3490. 1965. tb01424.x.

Luyten, P., Jones, J., Proctor, R., Tabor, A., Tett, P., Wild-Allen, K., 1999. COHERENS - A coupled hydrodynamical-ecological model for regional and shelf 
seas: User Documentation. Management Unit of the Mathematical Models of the north Sea, Belgium.

Madec, G., the NEMO team, 2008. NEMO ocean engine. Institut PierreSimon Laplace (IPSL). France. URL: https://www.nemo-ocean.eu/bibliography/ documentation/. note du Pôle de modélisation, No 27.

Marmefelt, E., Omstedt, A., 1993. Deep water properties in the Gulf of Bothnia. Continental Shelf Research , 169-187.

Marshall, J., Adcroft, A., Hill, C., Perelman, L., Heisey, C., 1997a. A finitevolume incompressible Navier Stokes model for studies of the ocean on parallel computers. Journal of Geophysical Research 102, 5753-5766.

Marshall, J., Hill, C., Perelman, L., Adcroft, A., 1997b. Hydrostatic, quasihydrostatic, and non-hydrostatic ocean modeling. Journal of Geophysical Research 102, 5733-5752.

Marzban, C., Wang, R., Kong, F., Leyton, S., 2011. On the effect of correlations on rank histograms: Reliability of temperature and wind speed forecasts from finescale ensemble reforecasts. Monthly Weather Review 139, 295-310.

Mazur-Marzec, H., 2006. Toxic Nodularia spumigena blooms in the coastal waters of the Gulf of Gdansk: a ten-year survey. OCEANOLOGIA 48, 255-273.

McGillicuddy, D.J., 2016. Mechanisms of physical-biologicalbiogeochemical interaction at the oceanic mesoscale. Annual Review of Marine Science 8, 125-159. URL: https://doi.org/10.1146/ annurev-marine-010814-015606, doi:10.1146/annu rev-marine-010814-015606, arXiv: https ://doi.org/10.1146/annurev-marine-010814-015606. pMID: 26359818.

Meier, H.E.M., 2001. On the parameterization of mixing in threedimensional Baltic Sea models. Journal of Geophysical Research: Oceans 106, 30997-31016. URL: https://agupubs.onlinelibrary. wiley.com/doi/abs/10.1029/2000JC000631, doi:10.1029/2000Jc000631, arXiv: https://agupubs . onlinelibrary.wiley. com/doi/pdf/10.1029/2000Jc000631.

Meier, H.E.M., Andersson, H.C., Arheimer, B., Donnelly, C., Eilola, K., Gustafsson, B.G., Kotwicki, L., Neset, T.S., Niiranen, S., Piwowarczyk, J., Savchuk, O.P., Schenk, F., Węsławski, J.M., Zorita, E., 2014. Ensemble modeling of the Baltic Sea ecosystem to provide scenarios for management. AMBIO 43, 37-48. URL: https://doi.org/10.1007/s13280-013-0475-6, doi:10. 1007/s13280- 013- 0475- 6.

Meier, H.E.M., Feistel, R., Piechura, J., Arneborg, L., Burchard, H., Fiekas, V., Golenko, N., Kuzmina, N., Mohrholz, V., Nohr, C., et al., 2006. Ventilation of the Baltic Sea deep water: A brief review of present knowledge from observations and models. Oceanologia 48.

Melzner, F., Thomsen, J., Koeve, W., Oschlies, A., Gutowska, M.A., Bange, H.W., Hansen, H.P., Körtzinger, A., 2013. Future ocean acidification will be amplified by hypoxia in coastal habitats. Marine Biology 160, 1875-1888.

Metropolis, N., Ulam, S., 1949. The Monte Carlo Method. Journal of the American Statistical Association 44, 335-341. URL: https://www.tandfonline.com/ doi/abs/10.1080/01621459.1949.10483310, doi:10.1080/01621459.1949.10483310, arXiv: https://www. tandfonline. com/doi/pdf/10.1080/01621459.1949.10483310. pMID: 18139350 . 
Mohammadi-Aragh, M., Goessling, H., Losch, M., Hutter, N., Jung, T., 2018. Predictability of Arctic sea ice on weather time scales. Scientific reports 8, 1-7. URL: http://www.nature.com/articles/s41598-018-24660-0, doi:10.1038/ s41598- 018 - 24660 - $\odot$.

Mohrholz, V., 2018. Major Baltic inflow statistics - revised. Frontiers in Marine Science 5, 384. URL: https://www.frontiersin.org/article/10.3389/fmars.2018. 00384, doi:10.3389/fmars.2018.00384.

Mohrholz, V., Naumann, M., Nausch, G., Krüger, S., Gräwe, U., 2015. Fresh oxygen for the Baltic Sea - an exceptional saline inflow after a decade of stagnation. Journal of Marine Systems 148, 152 - 166. URL: http://www. sciencedirect.com/science/article/pii/S0924796315000457, doi:https://doi.org/ 10. 1016/j . jmarsys. 2015.03.005.

Molteni, F., Buizza, R., Palmer, T., Petroliagis, T., 1996. The ECMWF ensemble prediction system: Methodology and validation. Quarterly Journal of the Royal Meteorological Society 122, 73-119.

Mylne, K.R., Evans, R.E., Clark, R.T., 2002. Multi-model multi-analysis ensembles in quasi-operational medium-range forecasting. Quarterly Journal of the Royal Meteorological Society 128, 361-384.

Myrberg, K., Andrejev, O., 2003. Main upwelling regions in the Baltic Sea - a statistical analysis based on three-dimensional modelling. Boreal Environmental Research 8, 97-112.

Mälkki, P., 2001. Oceanography in Finland 1918-2000. Geophysica 37, 225-259.

Niemi, A., 1979. Blue-green algal blooms and N:P ratio in the Baltic Sea. Acta Botanica Fennica 110, 57-61.

Ninove, F., Traon, P.Y.L., Remy, E., Guinehut, S., 2016. Spatial scales of temperature and salinity variability estimated from Argo observations. Ocean Science $12,1-7$.

Nissling, A., Johansson, U., Jacobsson, M., 2006. Effects of salinity and temperature conditions on the reproductive success of turbot (Scophthalmus maximus) in the Baltic Sea. Fisheries Research 80, 230 - 238. URL: http://www.sciencedirect.com/science/article/pii/S0165783606001469, doi:https: //doi.org/10.1016/j. fishres.2006.04.005.

Norman, M., Parampil, S.R., Rutgersson, A., Sahlée, E., $2013 . \quad$ Influence of coastal upwelling on the air-sea gas exchange of $\mathrm{CO}_{2}$ in a Baltic Sea basin. Tellus B: Chemical and Physical Meteorology 65, 21831. URL: https://doi.org/10.3402/tellusb.v65i0.21831, doi:10.3402/tellusb. v65i0.21831, arXiv:https://doi.org/10.3402/tellusb.v65i0.21831.

Nowicki, A., Janecki, M., Dzierzbicka-Głowacka, L., 2019. Operational system for automatic coastal upwelling detection in the Baltic Sea based on the 3D CEMBS model. Journal of Operational Oceanography , 112URL: https://doi.org/10.1080/1755876X.2019.1569748, doi:10.1080/1755876X. 2019.1569748, arXiv: https://doi.org/10.1080/1755876X.2019.1569748.

Palmén, E., 1930. Untersuchungen über die Strömungen in den Finnland umgebenden Meeren. Soc. Scient. Fenn., Comm. Phys.-Math. V. In German. 
Pellikka, H., Leijala, U., Johansson, M.M., Leinonen, K., Kahma, K.K., 2018. Future probabilities of coastal floods in Finland. Continental Shelf Research 157, 32 - 42. URL: http://www.sciencedirect.com/science/article/pii/ S0278434316302060, doi:https://doi.org/10.1016/j.csr.2018.02.006.

Pinardi, N., Woods, J. (Eds.), 2002. Ocean forecasting: conceptual basis and applications. Springer Science \& Business Media, Berlin.

Placke, M., Meier, H.E.M., Gräwe, U., Neumann, T., Frauen, C., Liu, Y., 2018. Long-term mean circulation of the Baltic Sea as represented by various ocean circulation models. Frontiers in Marine Science 5, 287. URL: https://www. frontiersin.org/article/10.3389/fmars.2018.00287, doi:10.3389/fmars. 2018.00287.

Raateoja, M., 2013. Deep-water oxygen conditions in the Bothnian Sea. Boreal Environment Research 18, 235-250.

Raateoja, M., Kuosa, H., Hällfors, S., 2011. Fate of excess phosphorus in the Baltic Sea: A real driving force for cyanobacterial blooms? Journal of Sea Research 65, 315 - 321. URL: http://www.sciencedirect.com/science/article/pii/ S1385110111000050, doi:https://doi.org/10.1016/j . seares.2011.01.004.

Riser, S.C., Freeland, H.J., Roemmich, D., Wijffels, S., Troisi, A., Belbéoch, M., Gilbert, D., Xu, J., Pouliquen, S., Thresher, A., Le Traon, P.Y., Maze, G., Klein, B., Ravichandran, M., Grant, F., Poulain, P.M., Suga, T., Lim, B., Sterl, A., Sutton, P., Mork, K.A., Vélez-Belchí, P.J., Ansorge, I., King, B., Turton, J., Baringer, M., Jayne, S.R., 2016. Fifteen years of ocean observations with the global Argo array. Nature Climate Change 6, 145.

Roemmich, D., Boebel, O., Desaubies, Y., Freeland, H., Kim, K., King, B., Le Traon, P.Y., Molinari, R., Owens, B.W., Riser, S., Send, U., Takeuchi, K., Wijffels, S., 2001. Observing the Oceans in the 21st Century. chapter Argo: The Global Array of Profiling Floats. URL: https://archimer.ifremer.fr/doc/00090/20097/.

Roemmich, D., Church, J., Gilson, J., Monselesan, D., Sutton, P., Wijffels, S., 2015. Unabated planetary warming and its ocean structure since 2006. Nature climate change 5,240 .

Rolff, C., Elfwing, T., 2015. Increasing nitrogen limitation in the Bothnian Sea, potentially caused by inflow of phosphate-rich water from the Baltic Proper. Ambio 44, 601-611.

Rönnberg, C., Bonsdorff, E., 2004. Baltic sea eutrophication: area-specific ecological consequences. Hydrobiologia 514, 227-241. URL: https://doi.org/10.1023/B: HYDR.0000019238.84989.7f, doi:10.1023/B: HYDR. 0000019238.84989.7f.

Ruhl, H.A., André, M., Beranzoli, L., Çağatay, M.N., Colaço, A., Cannat, M., Dañobeitia, J.J., Favali, P., Géli, L., Gillooly, M., Greinert, J., Hall, P.O., Huber, R., Karstensen, J., Lampitt, R.S., Larkin, K.E., Lykousis, V., Mienert, J., Miranda, J.M., Person, R., Priede, I.G., Puillat, I., Thomsen, L., Waldmann, C., 2011. Societal need for improved understanding of climate change, anthropogenic impacts, and geo-hazard warning drive development of ocean observatories in European seas. Progress in Oceanography 91, 1-33. URL: http://www.sciencedirect.com/science/article/pii/S0079661111000383, doi:https: //doi.org/10.1016/j. pocean. 2011.05.001. 
Ruokanen, L., Kaitala, S., Fleming, V., Maunula, P., 2003. Alg@line-joint operational unattended phytoplankton monitoring in the Baltic Sea, in: H. Dahlin, N.C. Flemming, K.N., Petersson, S. (Eds.), Building the European Capacity in Operational Oceanography, Proceedings of the Third International Conference on EuroGOOS. Elsevier. volume 69 of Elsevier Oceanography Series, pp. 519 522 .

Räsänen, T., Laakkonen, S., 2007. Cold war and the environment: The role of Finland in international environmental politics in the Baltic Sea region. Ambio $36,229-36$.

Sandén, P., Danielsson, Å., 1995. Spatial properties of nutrient concentrations in the Baltic Sea. Environmental Monitoring and Assessment 34, 289-307. URL: https://doi.org/10.1007/BF00554799, doi:10.1007/BF00554799.

Särkkä, J., Kahma, K.K., Kämäräinen, M., Johansson, M.M., Saku, S., 2017. Simulated extreme sea levels at Helsinki. Boreal Environment Research 22, 299-315.

Schiller, A., Brassington, G.B., 2011. Operational oceanography in the 21st century. Springer Science \& Business Media.

Schroeder, K., Chiggiato, J., Josey, S., Borghini, M., Aracri, S., Sparnocchia, S., 2017. Rapid response to climate change in a marginal sea. Scientific reports 7 , 4065 .

von Schuckmann, K., Palmer, M., Trenberth, K., Cazenave, A., Chambers, D., Champollion, N., Hansen, J., Josey, S., Loeb, N., Mathieu, P.P., Meyssignac, B., Wild, M., 2016. An imperative to monitor Earth's energy imbalance. Nature Climate Change 6, 138.

Seifert, T., Kayser, B., 1995. A high resolution spherical grid topography of the Baltic Sea. Meereswissenschaftliche Berichte 9, 72-88.

She, J., Allen, I., Buch, E., Crise, A., Johannessen, J.A., Le Traon, P.Y., Lips, U., Nolan, G., Pinardi, N., Reißmann, J.H., Siddorn, J., Stanev, E., Wehde, H., 2016. Developing European operational oceanography for Blue Growth, climate change adaptation and mitigation, and ecosystem-based management. Ocean Science 12, 953-976. URL: https://www.ocean-sci.net/12/953/2016/, doi:10.5194/ os - 12- 953 - 2016.

Siedlecki, S.A., Kaplan, I.C., Hermann, A.J., Nguyen, T.T., Bond, N.A., Newton, J.A., Williams, G.D., Peterson, W.T., Alin, S.R., Feely, R.A., 2016. Experiments with seasonal forecasts of ocean conditions for the northern region of the California Current upwelling system. Scientific Reports 6, 27203.

Sitarz, D., 1993. Agenda 21: The earth summit strategy to save our planet.

Sproson, D., Sahlée, E., 2014. Modelling the impact of Baltic Sea upwelling on the atmospheric boundary layer. Tellus A: Dynamic Meteorology and Oceanography 66, 24041. URL: https://doi.org/10.3402/tellusa.v66.24041, doi:10.3402/tellusa. v66.24041, arXiv:https://doi.org/10.3402/tellusa.v66.24041.

Stigebrandt, A., 2001. Physical oceanography of the Baltic Sea, in: Wulff, F.V., Rahm, L.A., Larsson, P. (Eds.), A systems analysis of the Baltic Sea. SpringerVerlag, Berlin Heidelberg. volume 148. chapter 2, pp. 19-74. 
Stipa, T., Skogen, M., Sehested Hansen, I., Eriksen, A., Hense, I., Kiiltomäki, A., Søiland, H., Westerlund, A., 2003. Short-term effects of nutrient reductions in the North Sea and the Baltic Sea as seen by an ensemble of numerical models. Meri - Report Series of the Finnish Institute of Marine Research 49, 43-70.

Stommel, H., 1963. Varieties of oceanographic experience. Science 139, 572-576.

SYKE, 2015. Marcoast service for water and sea surface temperatures (SST). accessed 15 january 2015. http://www.environment.fi/seasurfacetemperature. NOAA AVHRR satellite data, processing by SYKE in the GMES Downstream framework in ESA MarCoast 2 project.

SYKE, 2018a. The risk of significant blue-green algae blooms in summer 2018 is lower than earlier years in Finnish marine areas. URL: http://www.syke. fi/en-US/Current/The_risk_of_significant_bluegreen_algae_(47031). press Release 2018-06-07. Downloaded 2018-10-12.

SYKE, 2018b. Summary of algal bloom monitoring 2018: Sweltering summer brought exceptional cyanobacterial surface blooms to sea areas, in lakes abundant cyanobacterial blooms took place earlier. URL: http://www.syke.fi/en-US/Current/Algal_reviews/Summary_reviews/ Summary_of_algal_bloom_monitoring_2018_S(47752). summary Review 201808-30. Downloaded 2018-10-12.

Talagrand, O., 1999. Evaluation of probabilistic prediction systems, in: Workshop proceedings" Workshop on predictability", 20-22 October 1997, ECMWF, Reading, UK.

Tedesco, L., Piroddi, C., Kämäri, M., Lynam, C., 2016. Capabilities of Baltic Sea models to assess environmental status for marine biodiversity. Marine Policy 70, 1 - 12. URL: http://www.sciencedirect.com/science/article/pii/ S0308597X16301932, doi:https://doi.org/10.1016/j . marpol.2016.04.021.

Thompson, A.F., Chao, Y., Chien, S., Kinsey, J., Flexas, M.M., Erickson, Z.K., Farrara, J., Fratantoni, D., Branch, A., Chu, S., Troesch, M., Claus, B., Kepper, J., 2017. Satellites to seafloor: Toward fully autonomous ocean sampling. Oceanography $30,160-168$.

Thomson, R.E., Emery, W.J., 2014. Data analysis methods in physical oceanography. 3 ed., Elsevier, 225, Wyman Street, Waltham, MA 02451, USA.

Tonani, M., Balmaseda, M., Bertino, L., Blockley, E., Brassington, G., Davidson, F., Drillet, Y., Hogan, P., Kuragano, T., Lee, T., Mehra, A., Paranathara, F., Tanajura, C.A., Wang, H., 2015. Status and future of global and regional ocean prediction systems. Journal of Operational Oceanography 8, s201-s220. URL: https://doi.org/10.1080/1755876X.2015.1049892, doi:10. 1080/1755876X. 2015. 1049892, arXiv: https://doi.org/10.1080/1755876X.2015.1049892.

Toompuu, A., Wulff, F., 1996. Optimum spatial analysis of monitoring data on temperature, salinity and nutrient concentrations in the Baltic Proper. Environmental Monitoring and Assessment 43, 283-308. URL: https://doi.org/ 10.1007/BF00394455, doi:10.1007/BF00394455.

Treguier, A.M., Chassignet, E.P., Boyer, A.L., Pinardi, N., 2017. Modeling and forecasting the "weather of the ocean" at the mesoscale. Journal of Marine Research 75 . 
Tsumune, D., Tsubono, T., Aoyama, M., Hirose, K., 2012. Distribution of oceanic ${ }^{137} \mathrm{Cs}$ from the Fukushima Dai-ichi Nuclear Power Plant simulated numerically by a regional ocean model. Journal of Environmental Radioactivity 111, 100 108. URL: http://www.sciencedirect.com/science/article/pii/S0265931X11002463, doi:https://doi.org/10.1016/j . jenvrad.2011.10.007. environmental Impacts of the Fukushima Accident (Part I).

Tuomi, L., 2014. On modelling surface waves and vertical mixing in the Baltic Sea. Ph.D. thesis. URL: http://urn.fi/URN:ISBN:978-951-697-810-2.

Tuomi, L., Myrberg, K., Lehmann, A., 2012. The performance of the parameterisations of vertical turbulence in the 3D modelling of hydrodynamics in the Baltic Sea. Continental Shelf Research 50-51, $64-79$. URL: http://www.sciencedirect.com/science/article/pii/S027843431200221X, doi:https: //doi.org/10.1016/j.csr.2012.08.007.

Tyrrell, T., 1999. The relative influences of nitrogen and phosphorus on ocean primary production. Nature $400,525-531$.

Uiboupin, R., Laanemets, J., Sipelgas, L., Raag, L., Lips, I., Buhhalko, N., 2012. Monitoring the effect of upwelling on the chlorophyll a distribution in the Gulf of Finland (Baltic Sea) using remote sensing and in situ data. Oceanologia 54, 395 - 419. URL: http://www.sciencedirect.com/science/article/ pii/S0078323412500205, doi:https://doi.org/10.5697/oc.54-3.395.

Uotila, J., Launiainen, J., Vihma, T., 1995. Analysis of the surface drift currents in the Bothnian Sea. Geophysica 31, 37-49.

Vahtera, E., Autio, R., Kaartokallio, H., Laamanen, M., 2010. Phosphate addition to phosphorus-deficient Baltic Sea plankton communities benefits nitrogenfixing cyanobacteria. Aquatic Microbial Ecology 60, 43-57.

Vahtera, E., Laanemets, J., Pavelson, J., Huttunen, M., Kononen, K., 2005. Effect of upwelling in the pelagic environment and bloom-forming cyanobacteria in the western Gulf of Finland, Baltic Sea. Journal of Marine Systems 58, 67-82.

Viktorsson, L., Almroth-Rosell, E., Tengberg, A., Vankevich, R., Neelov, I., Isaev, A., Kravtsov, V., Hall, P.O.J., 2012. Benthic phosphorus dynamics in the Gulf of Finland, Baltic Sea. Aquatic Geochemistry 18, 543-564. URL: https://doi.org/ 10.1007/s10498-011-9155-y, doi:10.1007/s10498-011- 9155 -y.

Wang, X., Chao, Y., Thompson, D.R., Chien, S.A., Farrara, J., Li, P., Vu, Q., Zhang, H., Levin, J.C., Gangopadhyay, A., 2013. Multi-model ensemble forecasting and glider path planning in the Mid-Atlantic Bight. Continental Shelf Research 63, S223 - S234. URL: http://www.sciencedirect.com/science/article/ pii/S0278434312001896, doi:https://doi.org/10.1016/j.csr.2012.07.006. coastal Ocean Observing System: Retrospective Reanalysis and Real-Time Forecasting.

Wasmund, N., Nausch, G., Voss, M., 2012. Upwelling events may cause cyanobacteria blooms in the Baltic Sea. Journal of Marine Systems 90, 67 - 76. URL: http://www.sciencedirect.com/science/article/pii/S0924796311002016, doi:https : //doi .org/10 . 1016/j . jmarsys . 2011.09.001.

Westerlund, A., 2018. Modelling circulation dynamics in the northern Baltic Sea. Ph.D. thesis. URL: http://urn.fi/URN:ISBN:978-952-336-055-6. 
Westerlund, A., Tuomi, L., 2016. Vertical temperature dynamics in the Northern Baltic Sea based on 3D modelling and data from shallow-water Argo floats. Journal of Marine Systems 158, 34 - 44. URL: http://www. sciencedirect.com/science/article/pii/S0924796316000191, doi:https://doi.org/ 10.1016/j . jmarsys.2016.01.006.

Wilks, D., 2011. Chapter 8 - forecast verification, in: Wilks, D.S. (Ed.), Statistical Methods in the Atmospheric Sciences. Academic Press. volume 100 of International Geophysics, pp. 301 - 394. URL: http://www. sciencedirect.com/science/article/pii/B9780123850225000087, doi:https://doi. org/10.1016/B978- 0-12-385022-5.00008- - .

Williams, N.L., Juranek, L.W., Feely, R.A., Johnson, K.S., Sarmiento, J.L., Talley, L.D., Dickson, A.G., Gray, A.R., Wanninkhof, R., Russell, J.L., Riser, S.C., Takeshita, Y., 2017. Calculating surface ocean $\mathrm{pCO}_{2}$ from biogeochemical Argo floats equipped with $\mathrm{pH}$ : An uncertainty analysis. Global Biogeochemical Cycles 31, 591-604. URL: https://agupubs.onlinelibrary. wiley.com/doi/abs/10.1002/2016GB005541, doi:10.1002/2016GB005541, arXiv: https://agupubs. onlinelibrary.wiley.com/doi/pdf/10.1002/2016GB005541.

Witting, R., 1912. Zusammenfassende übersicht der Hydrographie des Bottnischen und Finnischen Meerbusens und der Nördlichen Ostsee. Finnländische hydrographisch-biologische Untersuchungen 7.

Wong, A.P.S., Riser, S.C., 2011. Profiling float observations of the upper ocean under sea ice off the Wilkes Land coast of Antarctica. Journal of Physical Oceanography 41, 1102-1115. URL: https://doi.org/10.1175/2011JPO4516.1, doi:10.1175/2011JP04516.1, arXiv: https://doi.org/10.1175/2011JP04516.1.

Wong, A.P.S., Riser, S.C., 2013. Modified shelf water on the continental slope north of Mac Robertson Land, East Antarctica. Geophysical Research Letters 40, 6186-6190. URL: https://agupubs.onlinelibrary. wiley.com/doi/abs/10.1002/2013GL058125, doi:10.1002/2013GL058125, arXiv: https://agupubs. onlinelibrary.wiley. com/doi/pdf/10. 1002/2013GL058125.

Xing, X., Morel, A., Claustre, H., Antoine, D., D’Ortenzio, F., Poteau, A., Mignot, A., 2011. Combined processing and mutual interpretation of radiometry and fluorimetry from autonomous profiling Bio-Argo floats: Chlorophyll a retrieval. Journal of Geophysical Research: Oceans 116. URL: https://agupubs.onlinelibrary. wiley.com/doi/abs/10.1029/2010JC006899, doi:10.1029/2010Jc006899, arXiv: https://agupubs . onlinelibrary.wiley. com/doi/pdf/10.1029/2010Jc006899.

Zhurbas, V., Laanemets, J., Vahtera, E., 2008. Modeling of the mesoscale structure of coupled upwelling/downwelling events and the related input of nutrients to the upper mixed layer in the Gulf of Finland, Baltic Sea. Journal of Geophysical Research: Oceans 113. URL: https://agupubs.onlinelibrary. wiley.com/doi/abs/10.1029/2007JC004280, doi:10.1029/2007Jc004280, arXiv: https://agupubs. onlinelibrary.wiley. com/doi/pdf/10.1029/2007Jc004280.

Österblom, H., Hansson, S., Larsson, U., Hjerne, O., Wulff, F., Elmgren, R., Folke, C., 2007. Human-induced trophic cascades and ecological regime shifts in the Baltic Sea. Ecosystems 10, 877-889. URL: https://doi.org/10.1007/ s10021-007-9069-0, doi:10.1007/s10021-007- 9069 - 0. 


\section{Licences \& Permissions}

\section{Publications}

Publication I (c)2018 The Authors. Published by Informa UK Limited, trading as Taylor \& Francis Group. This is an Open Access article distributed under the terms of the Creative Commons Attribution License (http://creativecommons.org/licenses/by/4.0/), which permits unrestricted use, distribution, and reproduction in any medium, provided the original work is properly cited.

Publication II and III (c)2018 The Authors. Both are open-access articles distributed under the terms of the Creative Commons Attribution License (CC BY). The use, distribution or reproduction in other forums is permitted, provided the original author(s) and the copyright owner(s) are credited and that the original publication in this journal is cited, in accordance with accepted academic practice. No use, distribution or reproduction is permitted which does not comply with these terms.

Publication IV is reproduced with the permission of the Taylor \& Francis Group.

Publication V is reproduced with the permission of Elsevier, B.V.

\section{Data}

The Argo data were collected and made freely available by the International Argo Project and the national programmes that contribute to it (http://www.argo.ucsd.edu, http://argo.jcommops.org). Argo is a pilot programme of the Global Ocean Observing System.

The satellite SST data is available under Creative Commons By 4.0 International license and is processed by Finnish Environment Institute. 
Finnish Meteorological Institute Contributions 157

ISSN: 0782-6117

ISBN (paperback): 978-952-336-088-4

ISBN (pdf): 978-952-336-089-1

https://doi.org./10.35614/isbn.9789523360891

○

$\sqrt{\overline{2}}$

$\infty$

G

N

O

=

○高

f

$\infty \overline{\overline{2}}$

$\infty=$

$\infty$

ISBN 978-952-60-8848-8 (printed)

ISBN 978-952-60-8849-5 (pdf)

ISSN 1799-4934 (printed)

ISSN 1799-4942 (pdf)

Aalto University

School of Engineering

Department of Built Environment

www.aalto.fi

BUSINESS +

ECONOMY

ART +

DESIGN +

ARCHITECTURE

SCIENCE t

TECHNOLOGY

CROSSOVER

DOCTORAL

DISSERTATIONS 